\title{
Novel Bionanocompounds: Outer Membrane Protein A and Laccase Co-Immobilized on Magnetite Nanoparticles for Produced Water Treatment
}

\author{
Nathaly Rangel-Muñoz ${ }^{1}{ }^{\circledR}$, Andres Fernando González-Barrios ${ }^{2}$, Diego Pradilla ${ }^{2}$, \\ Johann F. Osma ${ }^{3}$ (D) and Juan C. Cruz ${ }^{1,4, *(1)}$ \\ 1 Department of Biomedical Engineering, Universidad de Los Andes, Carrera 1 este No 19A-40, \\ Bogotá 111711, Colombia; in.rangel@uniandes.edu.co \\ 2 Grupo de Diseño de Productos y Procesos (GDPP), Department of Chemical and Food Engineering, \\ Universidad de los Andes, Carrera. 1 este No. 19a-40, Bogotá 111711, Colombia; \\ andgonza@uniandes.edu.co (A.F.G.-B.); d-pradil@uniandes.edu.co (D.P.) \\ 3 CMUA, Department of Electrical and Electronic Engineering, Universidad de Los Andes, \\ Carrera. 1 este No. 19a-40, Bogotá 111711, Colombia; jf.osma43@uniandes.edu.co \\ 4 School of Chemical Engineering and Advanced Materials, The University of Adelaide, \\ Adelaide 5005, Australia \\ * Correspondence: jc.cruz@uniandes.edu.co
}

Received: 4 November 2020; Accepted: 13 November 2020; Published: 17 November 2020

check for updates

\begin{abstract}
The oil and gas industry generates large amounts of oil-derived effluents such as Heavy Crude Oil (HCO) in water (W) emulsions, which pose a significant remediation and recovery challenge due to their high stability and the presence of environmentally concerning compounds. Nanomaterials emerge as a suitable alternative for the recovery of such effluents, as they can separate them under mild conditions. Additionally, different biomolecules with bioremediation and interfacial capabilities have been explored to functionalize such nanomaterials to improve their performance even further. Here, we put forward the notion of combining these technologies for the simultaneous separation and treatment of $\mathrm{O} / \mathrm{W}$ effluent emulsions by a novel co-immobilization approach where both OmpA (a biosurfactant) and Laccase (a remediation enzyme) were effectively immobilized on polyether amine (PEA)-modified magnetite nanoparticles (MNPs). The obtained bionanocompounds (i.e., MNP-PEA-OmpA, MNP-PEA-Laccase, and MNP-PEA-OmpA-Laccase) were successfully characterized via DLS, XRD, TEM, TGA, and FTIR. The demulsification of O/W emulsions was achieved by MNP-PEA-OmpA and MNP-PEA-OmpA-Laccase at $5000 \mathrm{ppm}$. This effect was further improved by applying an external magnetic field to approach $\mathrm{HCO}$ removal efficiencies of $81 \%$ and $88 \%$, respectively. The degradation efficiencies with these two bionanocompounds reached levels of between $5 \%$ and $50 \%$ for the present compounds. Taken together, our results indicate that the developed nanoplatform holds significant promise for the efficient treatment of emulsified effluents from the oil and gas industry.
\end{abstract}

Keywords: co-immobilization; demulsification and treatment; heavy crude oil; O/W emulsions; OmpA; Laccase; magnetite nanoparticles

\section{Introduction}

Research and development involving nanoparticles (NPs) has gained considerable attention during the last decade due to the wide spectrum of possible applications. NPs have unique properties, including nanometric size (which provides them with large surface areas), chemical stability in different environments, ease of synthesis, and low production costs [1]. NPs have 
been implemented for applications in a number industries including pharma [2], nutraceutical [3], food [4], agro-industrial [5], and cosmetics [6]. Moreover, they have been successfully explored as supports for the immobilization of various molecules of biological origin with the purpose of increasing their functionality and incorporating additional properties such as responsiveness to external stimuli; enhanced thermal, conformational, and long-term stability; and ease of transport and manipulation [7-11]. A group of molecules that has been successfully immobilized on NPs is proteins and peptides. Upon immobilization, these molecules extend their lifetimes, enhance their recyclability, and can even improve their biological function in non-native environments. This significant improvement ultimately leads to higher operation efficiencies and yields [11]. Moreover, bionanocompounds based on proteins and peptides immobilized on NPs have enabled a large body of applications in industrial wastewater treatment $[9,12,13]$.

The oil and gas industry has been traditionally perceived as environmentally harmful. As a result of extraction and production activities, petroleum production generates large volumes of harmful effluents [12]. An important fraction of the effluents encompassing produced water are in the form of residual Oil-in-Water emulsions $(\mathrm{O} / \mathrm{W})$ [13]. These emulsions are difficult to treat and dispose of adequately. Consequently, significant effort has been devoted to the development of methods for the recovery of natural water sources and the remediation of wastewaters resulting from oil production activities [14-17]. Emulsions are a special type of colloids where a liquid is dispersed in the form of droplets (dispersed phase) in a second immiscible liquid (continuous phase) with a different polarity [13]. O/W emulsion preparations have been recently developed for the petroleum industry as pipeline aids for the transport of crude oil-e.g., the commercially available product Orimulsion $^{\circledR}$ (BITOR, Salager et al., 2001) [18,19]. The high stability of these systems generates a number of difficulties for their removal and high operating costs mainly due to the required extreme operating temperature conditions and relatively low efficiencies [20].

Traditional methods for emulsified wastewater treatment are based on mechanical (ultrafiltration) [21], physical-chemical (photocatalysis) [22], or biological (bioremediation) approaches [23]. The last group of processes has attracted significant attention and mainly refers to the incorporation of active biomolecules or whole microorganisms into different stages during the treatment of the recovered effluents [24]. This approach is advantageous due the low toxicity and environmental friendliness of these agents [25]. One of the most useful groups of biomolecules for emulsion bioremediation (due to their interfacial activity) are biosurfactants, which have been categorized into different families including lipids, proteins, and bacteria [24-28]. Despite the possible benefits, biosurfactants tend to face stability issues that compromise their performance, especially when subjected to operating conditions far from those observed in their native environments [29]. For this reason, their applicability has been largely limited to the food and biomedical industries, where the processing conditions are milder [26].

Proteins comprise a group of biosurfactants of great interest due to their superior performance [28]. Most of these have been derived from bacteria and are usually present in their membranes [27,30,31]. Outer Membrane Protein A (OmpA) is an example of a successful biosurfactant, which is a the transmembranal protein of Escherichia coli [28,32]. The surface activity of OmpA has been attributed to its amphiphilic structure, composed of two main hydrophilic and hydrophobic chains. The N-terminal (amino acids 1 to 171) is hydrophobic and consists of eight beta chains with six binding sites where organic compounds can interact. Meanwhile, the C-terminal (amino acids 180 to 325) is hydrophilic and located in the periplasm; therein, it binds to the peptidoglycan, thereby connecting it to the outer membrane [33]. OmpA was successfully tested as an amphipathic demulsifier in model dodecane-water emulsions; consequently, the potential use of OmpA for the treatment of refinery effluents has attracted significant interest [34-36]. The demulsification processes of crude oil emulsions have also been enabled by nanomaterials, as they have facilitated HCO removal [37]. This is attributed to their high surface/volume ratio, which is thought to be responsible for high interfacial activity [17,38]. Some of the most successful nanomaterials include graphene oxide nanoparticles [38,39], carbon nanotubes [15], 
and magnetite nanoparticles (MNP) [14,40]. For instance, MNPs have been employed to destabilize oil emulsions upon the application of magnetic fields [14-16,41,42].

In addition to difficult separation, HCO emulsions contain several recalcitrant compounds (i.e., phenols, acyclic acids, naphthenic acids, or saturated and aromatic carboxylic acids) that need to undergo chemical transformation to decrease their potential environmental impact [43,44]. The required transformations are traditionally conducted with the aid of ozonation and oxidation processes [45] or photocatalysis [46]. However, the use of microorganisms such as bacteria, yeasts, or algae for the degradation of those pollutants has been also considered an attractive route $[25,47,48]$. Alternatively, enzymes are considered efficient and selective catalysts for bioremediation processes, where they have been incorporated as highly active and selective agents for the transformation of the recalcitrant compounds [49,50]. One of the most effective families of enzymes for bioremediation purposes are Laccases, which belong to the multicopper oxidases and can catalyze the oxidation of various aromatic substrates. Accordingly, they have the ability to degrade compounds such as phenols, amines, and hydrolyzed poly-acrylamides [50-53].

An emerging idea for the comprehensive treatment of emulsified effluents is to combine some of the technologies discussed above. Thus far, such exploration has been only conducted for the bioremediation of the pollutants and particularly through enzymatic systems. For instance, Yi Hu et al. discussed combining Laccase and ABTS onto chitosan nanoparticles for 2,4-DCP removal. Similarly, Bernabé L. Rivas et al. tested the synergy between Agaricus bisporus and Trametes versicolor Laccases in diazinon degradation $[54,55]$. Here, we introduced the notion that superior results in separation and treatment can be achieved by combining the demulsifying properties of OmpA, the destabilizing and recoverability power of MNPs, and the catalytic activity of the Laccase enzyme. An avenue to accomplish this is through the co-immobilization of OmpA and Laccase molecules on MNPs. Nevertheless, several parameters need to be considered to assure that the proteins preserve their activity after immobilization. These include the surface chemistry of the support, enzyme packing density, enzyme charge, and isoelectric point [10]. Susceptibility to undergoing detrimental conformational changes upon contact with surfaces has been controlled by a number of strategies, including adsorption, covalent bonding, encapsulation, and the use of polymeric spacers (cross linking) [10,56]. Hydrophilic polymers have been successfully implemented for the covalent immobilization of several proteins [57]. One example of this is the polymers from the polyether amine (PEA) family, which provide flexibility and a local microenvironment that prevents conformational changes. The end result is a relatively large number of functional protein molecules on the surface of the material $[57,58]$.

This work is therefore dedicated to investigating whether, by co-immobilizing OmpA and a Laccase on MNPs, it is possible to separate O/W emulsions and reduce some of the environmentally harmful compounds present in them. We immobilized biomolecules with the aid of a PEA surface spacer to maintain high levels of functionality for both proteins-i.e., interfacial activity (OmpA) and catalytic competency (Laccase). First, the obtained bionanocompounds were chemically characterized with the aid of X-ray diffraction and FTIR spectroscopy. The physical properties were determined via DLS, TEM, and TGA. Finally, the immobilization yield was indirectly quantified with an ABTS oxidation assay for the Laccase molecules. The demulsifying effect of free MNPs, OmpA, and MNP-PEA-OmpA and MNP-PEA-OmpA-Laccase bionanocompounds was tested in a synthetic $\mathrm{O} / \mathrm{W}$ emulsion in the absence and presence of a magnetic field. Additionally, we identified an increase in the removal percentage of harmful compounds such as asphaltenes, alkenes, and aromatic molecules after treatment with the MNP-PEA-OmpA-Laccase bionanocompound.

\section{Materials and Methods}

\subsection{Materials}

Iron (II) chloride tetrahydrate 98\% (PanReac Quimica, SLU, Barcelona, Spain.) and Iron (III) chloride tetrahydrate (Merck, Munich, Germany), $98 \%$ sodium hydroxide $(\mathrm{NaOH})$, dimethylformamide 
(DMF) (PanReac Quimica, SLU, Barcelona, Spain), 25\% tetramethylammonium hydroxide (TMAH), 98\% (3-Aminopropyl) triethoxysilane (APTES), 98\% N-hydroxy succinimide (NHS), and 98\% N-[3-dimethylammino)-propyl]-N'-ethyl carbodiimide hydro- chloride (EDC) (Merck, Darmstadt, Germany) were used for MNP synthesis and functionalization. Tryptone, yeast extract, sodium chloride $(\mathrm{NaCl}) 98 \%$, lactose, and sodic phosphate $\left(\mathrm{Na}_{2} \mathrm{HPO}_{4}\right)$ were all purchased from Merck KGaA, (Darmstadt, Germany). Protein purification required the Profinity ${ }^{\mathrm{TM}}$ IMAC Resin (Bio-Rad Laboratories, Hercules, CA, USA) and buffers with sodium acetate $\left(\mathrm{C}_{2} \mathrm{H}_{3} \mathrm{NaO}_{2}\right), 99.9 \%$ acetic acid $(99.8 \%)\left(\mathrm{CH}_{3} \mathrm{COOH}\right)$ (PanReac Quimica, SLU, Barcelona, Spain.), 85\% phosphoric acid $\left(\mathrm{H}_{3} \mathrm{PO}_{4}\right)$, imidazole (99\%), nickel (II) sulfate 99.99\% ( $\mathrm{NiSO}_{4}$ ) (Merck, Darmstadt, Germany), and EDTA 99\% (PanReac AppliChem, Chicago, IL, USA). Jeffamine M-600 polyetheramine (PEA) (Huntsman Corporation, Woodland, TX, USA) was used as a surface spacer and oxidized with the aid of KMnO4 (Sigma-Aldrich, Munich, Germany) to render free terminal carboxyl groups for further conjugation. Laccase from Trametes versicolor $0.5 \mathrm{U} / \mathrm{mg}$, $\mathrm{HCl}, \mathrm{KMnO} 4$, Tween 20, sodium bicarbonate 99.7\% $\left(\mathrm{NaHCO}_{3}\right), 98 \%$ magnesium chloride, and TritonX were purchased from Sigma-Aldrich, Munich, Germany. The 97\% calcium chloride $\left(\mathrm{CaCl}_{2}\right)$ was from PanReac Quimica, SLU, Barcelona, Spain; the ultrapure petroleum ether was Merck KGaA, (Darmstadt,

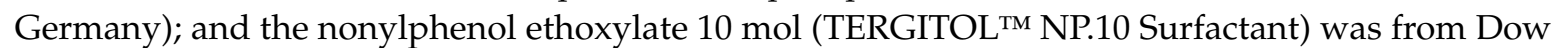
Chemical, Midland, MI, USA. Heavy crude oil (CO) from a Colombian oilfield was used as reported by Acosta et al. [59].

\subsection{Protein Production}

Outer membrane protein A (OmpA) was recombinantly expressed in Escherichia coli K-12 W3110/pCA24N OmpA ${ }^{+}$. Bacteria were cultured overnight at $37^{\circ} \mathrm{C}$ in Lurta-Bertani (LB) agar plates containing yeast extract $(5 \mathrm{~g} / \mathrm{L})$, tryptone $(10 \mathrm{~g} / \mathrm{L}), \mathrm{NaCl}(10 \mathrm{~g} / \mathrm{L})$, and chloramphenicol $(50 \mu \mathrm{g} / \mathrm{mL})$. Next, a colony was inoculated in LB medium $(25 \% \mathrm{NaCl}, 25 \%$ tryptone, $12.5 \%$ yeast extract, and $100 \mu \mathrm{g} / \mathrm{mL}$ of chloramphenicol) and incubated for $16 \mathrm{~h}$ at $37^{\circ} \mathrm{C}$ and $250 \mathrm{RPM}$. Subsequently, fresh LB medium (5 L) in a Bioflo/Celligen 115 Bioreactor (New Brunswick Scientific, Edison, NJ, USA) was inoculated with the previous culture and maintained for about $2 \mathrm{~h}$ at $37^{\circ} \mathrm{C}, 250 \mathrm{RPM}$, and a $2 \mathrm{~L} / \mathrm{min}$ air flow. The culture was grown until reaching an optical density of 0.8 at $600 \mathrm{~nm}$ (OD600 nm). At this point, the medium was fed with isopropylthio- $\beta$-galactoside (IPTG) $(2 \mathrm{mM})$ to induce expression. IPTG exposure was performed for $5 \mathrm{~h}$. Bacteria were then collected and concentrated with the aid of a $0.22 \mu \mathrm{m}$ cassette membrane in a parallel plate filter (Pellicon ${ }^{\circledR} 2$ Filters and Holders, Merck Millipore Corporatio, Burlington, MA, USA). The collected cells with overexpressed OmpA were lysed with an ultra-sonic tip Vibra-cell VCX-750 (Sonics \& materials Inc., Newton, CT, USA) after adding a lysis buffer $\left(\mathrm{NaH}_{2} \mathrm{PO}_{4}, \mathrm{NaCl}\right.$, Tween 20, TritonX). Sonication proceeded for 40 cycles (20 s on, $40 \mathrm{~s}$ off) at $37 \%$ amplitude in ice. The obtained lysate medium was centrifuged at $4500 \mathrm{RPM}$ and $4{ }^{\circ} \mathrm{C}$ for $2 \mathrm{~h}$ and the supernatant was recovered. Purification was conducted by passing the supernatant through a purification column packed with Profinity ${ }^{\mathrm{TM}} \mathrm{IMAC}$ Resins, following the manufacturer's instructions. Purified fractions were collected, and the presence of OmpA in each one of them was verified with sodium dodecyl sulfate polyacrylamide gel electrophoresis (SDS-PAGE). Fractions showing a single band at $35 \mathrm{kDa}$ were lyophilized to preserve protein structure and stored at $4{ }^{\circ} \mathrm{C}$ until further use.

\subsection{Protein Characterization}

OmpA protein was lyophilized for $48 \mathrm{~h}$ at $-80{ }^{\circ} \mathrm{C}$. The final concentration of the protein was quantified by colorimetric protein determination techniques using a commercial BCA Protein Assay Kit (Sigma-Aldrich, Munich, Germany) (Supplementary Figure S1). The secondary structure of OmpA was analyzed via second derivative methods [60] of its characteristic FTIR spectrum, as collected with a Bruker Alpha II FTIR Eco-ART (Bruker Optik GmbH, Ettlingen, Germany). Spectra were measured in the range of $4000-400 \mathrm{~cm}^{-1}$ with a spectral resolution of $2 \mathrm{~cm}^{-1}$ at room temperature. 


\subsection{Polyetheramine (PEA) Oxidation}

A total of $3 \mathrm{~g}$ of Jeffamine M- 600 polyetherimine (PEA) was oxidized in $50 \mathrm{~mL}$ of a $0.015 \mathrm{M}$ solution of $\mathrm{KMnO}_{4}$ following the protocol of Feng et al. [61]. The mixture was kept under magnetic stirring for $12 \mathrm{~h}$ at room temperature. The $\mathrm{MnO}_{2}$ precipitate resulting as byproduct of the oxidation reaction was filter under vacuum with a $0.7 \mu \mathrm{m}$ paper filter until obtaining a transparent solution. The $\mathrm{pH}$ of the sample was adjusted to 2.0 by adding $10 \mathrm{M}$ of hydrochloric acid $(\mathrm{HCl})$ dropwise. Excess $\mathrm{KMnO} 4$ and $\mathrm{HCl}$ was removed by dialysis using a 100-500 Da cut-off molecular weight membrane with ultra-pure water for $12 \mathrm{~h}$. Finally, the water excess in the PEA solution was removed in a rotary evaporator (Vap Value Digital Vertical Heidolph, Schwabach, Germany) under vacuum at $80^{\circ} \mathrm{C}$ for $6 \mathrm{~h}$. The PEA oxidation was verified by FTIR, and its approximate concentration was determined by the chemical titration of the carboxyl groups (acid value).

\subsection{Synthesis of Magnetite Nanoparticles}

Magnetite nanoparticles were synthesized by the co-precipitation method. Briefly, $2.528 \mathrm{~g}$ of $\mathrm{FeCl}_{2} \cdot 4 \mathrm{H}_{2} \mathrm{O}(2.73 \mathrm{mmol})$ and $7.56 \mathrm{~g}$ of $\mathrm{FeCl}_{3} \cdot 6 \mathrm{H}_{2} \mathrm{O}(27.96 \mathrm{mmol})$ were dissolved separately in $40 \mathrm{~mL}$ of ultra-pure water to obtain $0.3 \mathrm{M}$ and $0.7 \mathrm{M}$ solutions, respectively. Additionally, $5.6 \mathrm{~g}$ of $\mathrm{NaOH}$ were dissolved in $40 \mathrm{~mL}$ of water. Chlorides solutions were then mixed in the presence of $40 \mathrm{~mL}$ of ultra-pure water and $2 \mathrm{~mL}$ of $2 \%(v / v)$ solution of TMAH (to avoid agglomeration), followed by heating up to $90^{\circ} \mathrm{C}$. Finally, the $\mathrm{NaOH}$ solution was manually dropped into the chloride mixture at a rate of $3 \mathrm{~mL} / \mathrm{min}$ while maintaining vigorous agitation at $1500 \mathrm{RPM}$ and the temperature $a 0^{\circ} \mathrm{C}$. The reaction was carried out for $1 \mathrm{~h}$. The obtained MNPs were washed at least 3 times with ultra-pure water with the aid of a strong permanent magnet for rapid separation and sonicated in an ultrasonic bath (2800 Cleaner, Branson Ultrasonics, Brookfield, CT, USA) in between washes.

\subsection{MNP Characterizations}

The size of the obtained MNP was measured using a Dynamic Light Scattering (DLS) instrument (Zeta-Sizer Nano-ZS, Malvern Instruments, Malvern, UK) and Transmission Electron Microscopy (TEM) (Tecnai F20 Super Twin TMP, ThermoFisher, MA, USA). Additionally, the purity of the crystalline phase of magnetite was verified via X-Ray Diffraction (XRD). Finally, effective synthesis was confirmed by Fourier-transform infrared spectroscopy (FT-IR) and thermogravimetric analysis (TGA) (TA Instruments, New Castle, DE, USA). Infrared spectra were recorded using an A250/D FT-IR (Bruker, Billica, MA, USA). The FT-IR parameters were specified with the aid of the OPUS Spectroscopy Software (Bruker, Billica, MA, USA). Spectra were recorded in the range of $4000-400 \mathrm{~cm}^{-1}$ with a spectral resolution of $2 \mathrm{~cm}^{-1}$.

\subsection{OmpA and Laccase Immobilization: Magnetite-PEA-OmpA-Laccase Bionanocompounds}

The silanization of MNP was carried out with an initial sample of $100 \mathrm{mg}$ of MNP in $30 \mathrm{~mL}$ of ultra-pure water. The process was started by sonicating the MNP for $40 \mathrm{~min}$ to avoid agglomeration. Next, $200 \mathrm{~mL}$ of a $2.5 \%(v / v)$ solution of TMAH was added to help resuspending the MNP. Then, $20 \mu \mathrm{L}$ of $99 \%$ glacial acetic acid was added prior to the conjugation of APTES $(200 \mu \mathrm{L})$. This compound rendered free amine groups on the surface of the MNPs. The reaction was carried out at $60^{\circ} \mathrm{C}$ and $250 \mathrm{RPM}$ for $1 \mathrm{~h}$. Silanized nanoparticles were washed five times with ultra-pure water and $1.5 \%(w / v)$ $\mathrm{NaCl}$ solution to remove excess APTES, aided by a strong permanent magnet.

Silanized MNP was resuspended in $30 \mathrm{~mL}$ of ultra-pure water and sonicated for $40 \mathrm{~min}$. Then, $2 \mathrm{~mL}$ of $2 \%(v / v)$ of glutaraldehyde (GA) was added to the MNP sample and left under mechanical agitation at $250 \mathrm{RPM}$ and room temperature for $24 \mathrm{~h}$. Oxidized PEA was then conjugated to the obtained MNP-AP-GA by adding $1 \mathrm{~mL}$ of PEA solution in a 1:2 molar ratio with respect to the free amine groups. The reaction proceeded overnight at 250 RPM and room temperature. Finally, the PEA-coated 
magnetite nanoparticles were washed three times with ultra-pure water and three times with $1.5 \%$ $(w / v) \mathrm{NaCl}$ solution.

To obtain the MNP-PEA-OmpA-Laccase bionanocompounds, OmpA and Laccase were conjugated according to the calculations presented in Supplementary Data SI2. Both OmpA and Laccase were sequentially immobilized at a 1:1 molar ratio. Accordingly, the required amount of protein was suspended in $2 \mathrm{~mL}$ of ultra-pure water with $5 \mathrm{mg}$ of NHS and $5 \mathrm{mg}$ of EDC. The proteins were conjugated to the carboxyl groups of oxidized PEA (1 equivalent) by their $\mathrm{N}$-terminal to form amide bonds. After adding proteins, the reaction was conducted for $24 \mathrm{~h}$ at $250 \mathrm{RPM}$ and room temperature. Next, the samples were thoroughly washed with type I water (ultra-pure water with a resistivity $>18 \mathrm{M} \Omega$-cm and conductivity of $<0.056 \mu \mathrm{S} / \mathrm{cm}$ ) and the aid of a strong permanent magnet to remove excess reagents.

\subsection{Characterization of Magnetite-PEA-OmpA-Laccase Bionanocompounds}

Prior to characterization, an amount of each sample was lyophilized and subsequently characterized via FTIR and TGA. The obtained MNP-PEA-OmpA, MNP-PEA-Laccase, and MNP-PEA-OmpA-Laccase bionanocompounds were evaluated via Fourier Transform Infrared Spectroscopy (FTIR) by a Bruker Alpha II FTIR Eco-ATR (Bruker, Billica, MA, USA). Spectra were collected in the range of $4000-400 \mathrm{~cm}^{-1}$ with a spectral resolution of $2 \mathrm{~cm}^{-1}$. The second derivative of magnetite-PEA-OmpA-Laccase bionanocompounds was calculated with the OriginPro8 Software and subsequently employed to determine alterations in the secondary structure of proteins after immobilization $[2,60]$. TGA was performed to estimate the thermal stability of magnetite nanoparticles and bionanocompounds. The experiment was carried out with 5-10 $\mathrm{mg}$ of lyophilized sample, and the percentage of mass loss was recorded as a function of temperature from 10 to $800{ }^{\circ} \mathrm{C}$ at a heating rate $10^{\circ} \mathrm{C} /$ min under a nitrogen atmosphere.

\subsection{Crude Oil in Water (O/W) Emulsion Preparation}

The O/W emulsion formulation was based on previous studies by Aburto et al. [17,19]. The formulated emulsion contained $1 \mathrm{wt} \%$ of crude oil (dispersed phase) in water (continuous phase). Nonylphenol ethoxylate at $10 \mathrm{~mol}$ (NPE10) with HLB 13.2 was used as a surfactant to achieve a stable direct emulsion, as described by Loh et al. [62]. For stabilization, the continuous phase was prepared as a brine solution following the procedure described in Øye et al. [63,64]. The composition of the prepared brine is shown in Table 1.

Table 1. Ion content in brine.

\begin{tabular}{cc}
\hline \multirow{2}{*}{ Ion } & Concentration [ppm] \\
\cline { 2 - 2 } & Brine with All Ions \\
\hline $\mathrm{CL}^{-}$ & 62,819 \\
$\mathrm{Na}^{+}$ & 35,393 \\
$\mathrm{Ca}^{2+}$ & 3253 \\
$\mathrm{Mg}^{2+}$ & 909 \\
$\mathrm{HCO}^{3-}$ & 218 \\
$\mathrm{SO}_{4}{ }^{2-}$ & 49 \\
\hline
\end{tabular}

Stable emulsions were prepared as follows: (i) A volume of brine solution, corresponding to $97 \%$ of the total volume of the sample, was transferred to a vessel and heated to $60^{\circ} \mathrm{C}$ in a hot plate. This temperature was kept constant throughout the entire experiment. (ii) In a separate hot plate, $0.6 \mathrm{~mL}$ of heavy crude oil was transferred to a vessel and heated to $60^{\circ} \mathrm{C}$. A homogenizer was then connected to the hot brine container, which was equipped with a propeller located such that a ratio of propeller $(\mathrm{Da})$ to vessel diameter $(\mathrm{Dt})$ of about 1 (i.e., $\mathrm{Da} / \mathrm{Dt} \approx 1$ ) was maintained (see Supplementary Figure S2). (iii) A volume of NP-10mol (NP) surfactant was pipetted into the hot brine container 
with direct displacement to a total volume corresponding to $3 \%$ of the sample. (iv) The mixture was then homogenized at an initial speed of 2000 RPM to incorporate the surfactant while avoiding foam formation. (v) The pre-heated hot crude oil, corresponding to $1 \mathrm{wt} \%$ of the sample, was pipetted into the brine at a rate of $100 \mathrm{~mL} / \mathrm{s}$ by locating the tip close to the propeller. The agitation speed was then increased to $5000 \mathrm{RPM}$ for $15 \mathrm{~min}$ at $60^{\circ} \mathrm{C}$.

\subsection{Physical Stability of $\mathrm{O} / \mathrm{W}$ Emulsions}

Bottle testing is a widely used protocol for the easy assessment of demulsifier performance in oilfields. The incorporation of demulsifier at different concentrations is required, considering the significant amount of water added to homogenize it. The mixture was then added to the dispersed phase. Traditional bottle tests were carried out to determine the stability of the $\mathrm{O} / \mathrm{W}$ emulsion. The stability of $\mathrm{HCO}$ in water $(\mathrm{O} / \mathrm{W})$ emulsions was measured by following the changes in transmission signals and backscattering of light over time. This was also useful to assure the reproducibility of the emulsion manufacturing protocol. The $\Delta$ backscattering $(\Delta \mathrm{BS})$ measurement and the Turbiscan Stability Index (TSI) were recorded in a Turbiscan Lab Stability Analyzer (Formulaction SA, Toulouse, France) at conditions of transmission ( $0^{\circ}$ from the incident light beam) and backscattering $\left(135^{\circ}\right.$ from the incident light beam) by utilizing a pulsed near-infrared light source $(\lambda=850 \mathrm{~nm})$. For this purpose, samples were carefully transferred to a glass vial by preventing bubble formation at the top of the container. Measurements took place every minute for $1 \mathrm{~h}$ at room temperature $\left(25^{\circ} \mathrm{C}\right)$. $\mathrm{HCO}$ drops were imaged in an optical microscope with a 100X objective $(\mathrm{NA}=40)$. Image analysis was performed in the open access software Image $\mathrm{J}^{\circledR}$ (https://imagej.nih.gov/ij/).

\subsection{Demulsification Effect of MNP and OmpA in O/W Emulsion and Bottle Test}

The destabilizing effect of MNP and OmpA on the formulated O/W emulsion was evaluated separately in the Turbiscan for $1 \mathrm{~h}$ at room temperature. For this purpose, $16 \mathrm{~mL}$ of the O/W emulsion were placed in a glass vial along with 200, 500, 1000, or 5000 ppm (i.e., 3.2, 8, 16, $80 \mathrm{mg}$ or 500, $1000,5000 \mu \mathrm{g} / \mathrm{mL}$ ) of MNP or OmpA. The mixture was then homogenized at $100 \mathrm{RPM}$. The $\triangle \mathrm{BS}$ was monitored to determine the range of bionanocompound concentrations required for effective HCO removal.

\subsection{O/W Emulsion Separation and Treatment}

An effective concentration of $5000 \mathrm{ppm}(5000 \mu \mathrm{g} / \mathrm{mL})$ of OmpA and MNP for HCO removal was determined. Concentrations of bionanocompounds above $5000 \mathrm{ppm}$ failed to produce a further improvement in separation (data not shown). Such optimal concentration corresponded to an effective treatment ratio of 1:5 (i.e., $1 \mathrm{~mL}$ of $\mathrm{HCO}$ per $5 \mathrm{mg}$ of MNP-PEA-OmpA or MNP-PEA-OmpA-Laccase bionanocompound). Consequently, the demulsification tests with MNP-PEA-OmpA and MNP-PEA-OmpA-Laccase bionanocompounds were conducted at this concentration. After the incorporation of the bionanocompound, the sample was left at rest for $1 \mathrm{~h}$ to monitor separation by direct observation. Next, the bionanocompounds were recovered by placing a neodymium permanent magnet $(1.2 \mathrm{~T})$ at the bottom of the glass vial. Even though the bionanocompounds were easily recovered after treatment, further studies will be required to assess whether they could be recycled into the process. Subsequently, the remaining HCO in the sample was extracted with petroleum ether at a 1:3 mass ratio (sample:ether) in an ultrasound bath for $5 \mathrm{~min}$. The non-polar phase with the HCO dissolved in ether was collected and analyzed via UV-VIS spectrophotometer (GENESYS ${ }^{\mathrm{TM}} 10 \mathrm{~S}$, Thermo Fisher Scientific ${ }^{\mathrm{TM}}$, Waltham, MA, USA) at $225 \mathrm{~nm}$, where the HCO exhibits a characteristic peak [15]. The maximum content of HCO was recorded as relative percent by taking as reference samples in the absence of bionanocompounds (i.e., 100\% HCO content).

Finally, the bioremediation capacity of the MNP-PEA-OmpA/Laccase was evaluated via Gas Chromatography coupled to Mass Spectrometry (GC-MS) in an Agilent technologies (Santa Clara, 
CA, USA) $6890 \mathrm{~N}$ gas chromatography instrument coupled to a selective mass detector (MSD) 5975 in Full Scan mode. The GC was equipped with a HP-5MS column $(30 \mathrm{~m} \times 0.325 \mathrm{~m} \times 0.25 \mu \mathrm{m})$ operating at a $1.2 \mathrm{~mL} / \mathrm{min}$ flow rate. The initial oven temperature was held at $35^{\circ} \mathrm{C}$ for $5 \mathrm{~min}$. It was then increased at a rate of $8{ }^{\circ} \mathrm{C} / \mathrm{min}$ to $220^{\circ} \mathrm{C}$ and kept there for $5 \mathrm{~min}$ for a total detection time of $33.125 \mathrm{~min}$. The injection mode was pulsed splitless at a $10 \mathrm{~mL} / \mathrm{min}$ flow rate of Helium as entrainment gas at $200{ }^{\circ} \mathrm{C}$. The role of the Laccase was obtained by comparing the GC-MS results obtained with the full bionanocompound (i.e., MNP-PEA-OmpA-Laccase) with those obtained with the MNP-PEA-OmpA bionanocompound. Prior to injection into the GC-MS system, the sample was extracted with dichloromethane and concentrated to $1 \mathrm{~mL}$ with $\mathrm{N}_{2}$ flow. Quantitative analyses were conducted by measuring the relative content of molecules before and after treatment.

\section{Results and Discussion}

\subsection{Proteins, $P E A$ and $M N P$ s Characterization}

The purity of the obtained protein was approximately $94 \%$. Figure 1a shows the FTIR spectrum of dried OmpA. Peaks at $1651 \mathrm{~cm}^{-1}$ and $1513 \mathrm{~cm}^{-1}$ are associated with the Amide I and Amide II bands, respectively. The peak at $1260 \mathrm{~cm}^{-1}$ corresponds to the $\mathrm{C}-\mathrm{O}$ stretching vibrations. The peaks at 1059 and $3200 \mathrm{~cm}^{-1}$ can be attributed to the N-H stretching bands vibration [65]. The secondary structural changes of OmpA were determined by the second derivative of Amide I band (Supplementary Figure S3). Peak assignment was according to previous reports and can be consulted elsewhere [2]. The Amide I was selected for this deconvolution because is the most sensitive spectral region of the protein which originates from the $\mathrm{C}=\mathrm{O}$ stretching vibration of the amide group coupled with the in-phase bending of the N-H bond and stretching of the C-N bond [60]. Purified fractions of OmpA were confirmed in the SDS-PAGE gel, as shown in Figure $1 \mathrm{~b}$. The red arrow $(\sim 35 \mathrm{kDa})$ indicates the approximate molecular weight of OmpA, as reported previously [35]. Lanes 2-4 are the collected fractions after recovering the lysis supernatant and the first washing buffer, while lanes 5-10 are fractions collected after elution from the Ni column.

(a)

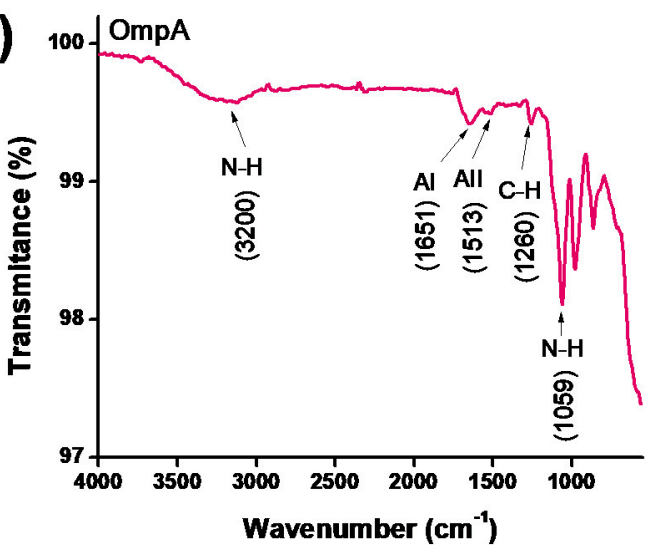

(b) $\mathrm{kDa}$

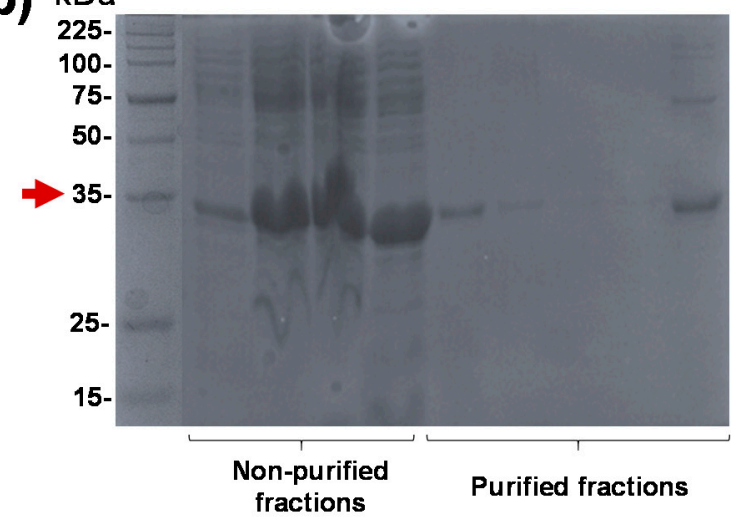

Figure 1. (a). FTIR spectrum of the dried OmpA protein. (b). Sodium dodecyl sulfate polyacrylamide gel electrophoresis (SDS-PAGE) of collected fractions during the purification procedure. Lane 1 shows the molecular weight marker while lanes 2 to 4 are for fractions collected of lysate supernatant and after washing. Lanes 5 to 10 are for fractions after elution from the Ni column. The band at about $\sim 35 \mathrm{kDa}$ corresponds to the OmpA.

Figure 2a shows the hydrodynamic diameter distribution of magnetite nanoparticles (MNP) as determined by DLS. The hydrodynamic diameter of bare MNPs approached an average of $80 \mathrm{~nm}$ with a polydispersity index (PI) of $22.4 \%$. The average diameter of MNPs was used to calculate the maximum number of protein molecules that can be immobilized on the surface (Supplementary Materials, Section SI2). The XRD diffractogram of powder MNPs is shown in Figure 2b. To appropriately interpret 
the data, the obtained diffractogram was smoothed and filtered out by means of a Savitzky-Golay Filter [66]. Subsequently, peaks corresponding to the Bragg diffraction planes of the crystalline phase of $\mathrm{Fe}_{3} \mathrm{O}_{4}$ were identified $(200,311,400,422,511,400)$ and corroborated the absence of precursor impurities and unwanted crystalline phases such as Hematite [67]. TEM images show various aggregates with individual particles exhibiting an average diameter of $\sim 30 \mathrm{~nm}$ (Figure 2c). Sizes of aggregates estimated from DLS and TEM measurements might not be comparable because in DLS, the sample is suspended in an aqueous medium, while for TEM the samples are dried out at room temperature before observation, which might lead to uncontrolled aggregation processes. Additionally, the drying process might induce the formation of salt crystals from excess reagents [68].

PEA oxidation was confirmed by Fourier transformed infrared spectroscopy (FTIR). Figure 2d shows the FTIR spectra of both PEA and oxidized PEA. Prior to oxidation, FTIR spectrum of PEA shows two absorption bands at around $1098 \mathrm{~cm}^{-1}$, which can be attributed to the C-O-H stretching vibration and an additional band at $1471 \mathrm{~cm}^{-1}$, which can be correlated with the $\mathrm{C}-\mathrm{H}$ bending vibration. Compared to the PEA IR spectrum, oxidized PEA exhibits three different vibrational bands at about 1645,1370 , and $1304 \mathrm{~cm}^{-1}$, which can be explained by the presence of $\mathrm{C}=\mathrm{O}$ stretching, $\mathrm{C}-\mathrm{H}$ bending, and $\mathrm{O}-\mathrm{H}$ stretching, respectively. Of interest are the $\mathrm{C}=\mathrm{O}$ stretching bands at 1645 and $3350 \mathrm{~cm}^{-1}$, because they can be associated with the $\mathrm{COOH}$ bonds of carboxyl groups needed for the conjugation of OmpA and Laccase. The peak at $2867 \mathrm{~cm}^{-1}$ corresponds to the amorphous PEA (C-H asymmetric stretching) [61].

(a)

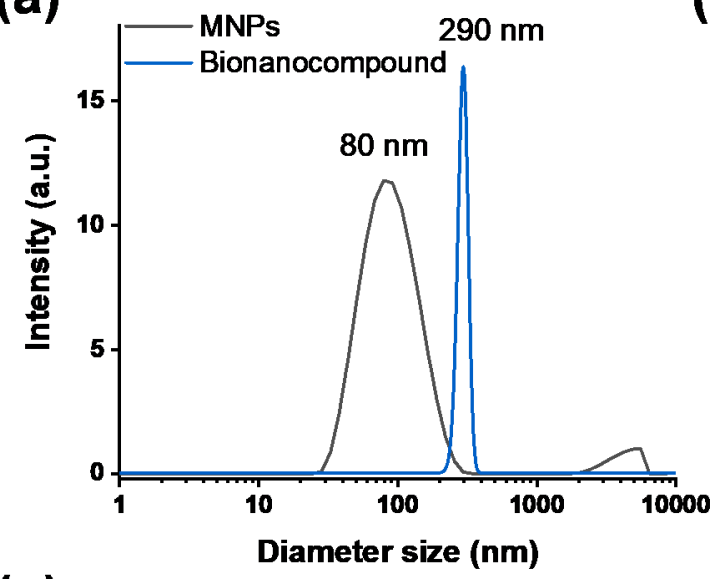

(c)

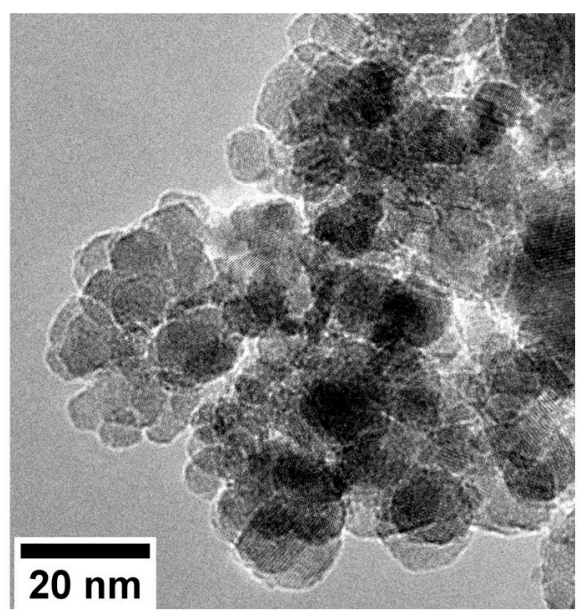

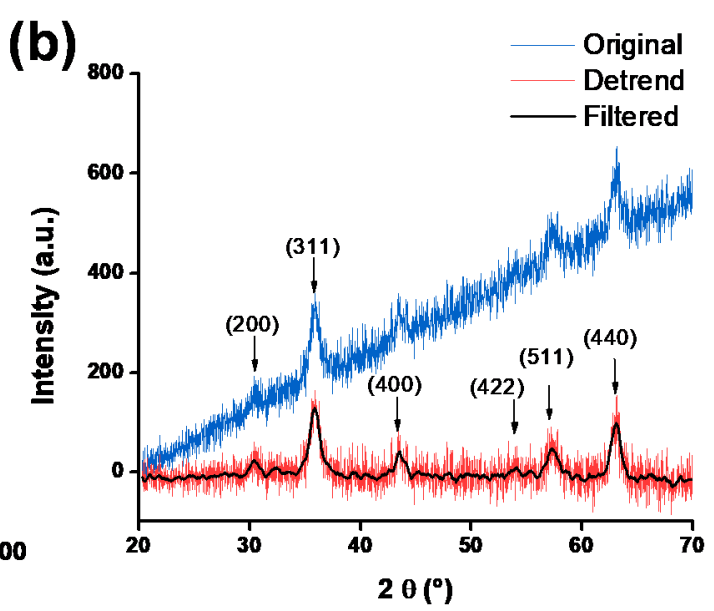

(d)

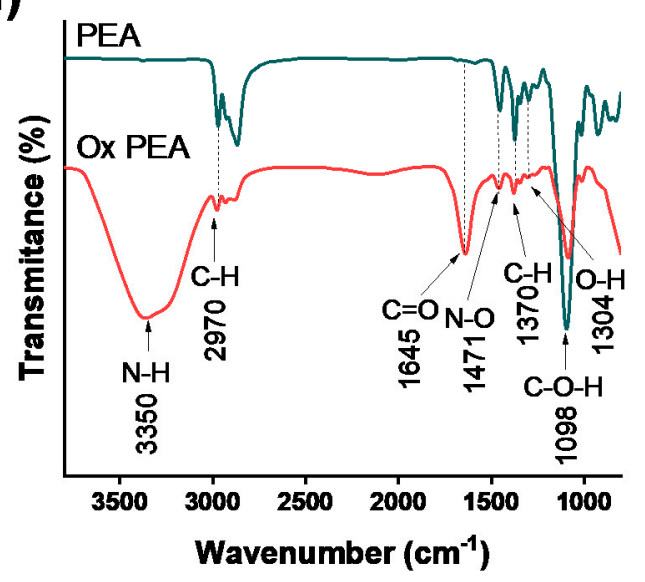

Figure 2. Magnetic nanoparticle (MNP) characterizations. (a) DLS histogram of the size distribution of MNP (gray) and MNP-PEA-OmpA/Laccase bionanocompound (blue). (b) XRD diffractogram of the dried MNPs. (c) TEM micrograph of MNPs. (d) FTIR spectra of PEA (green) and oxidized PEA (red). 


\subsection{Bionanocompounds Characterization}

The hydrodynamic diameter of the bionanocompound is reported in Figure 2a (blue). Contrary to the case of MNPs, after functionalization with OmpA and Laccase the average size approached $290 \mathrm{~nm}$ with a PI of $49 \%$. The conjugation of OmpA and Laccase on PEA-modified MNP is schematically shown in Scheme 1e. Successful conjugation was confirmed by FTIR, TGA and an enzymatic activity assay. The FTIR spectra after each conjugation step are shown in Figure 3a. Bare magnetite (MNP) shows an absorption band at $566 \mathrm{~cm}^{-1}$, which can be attributed to the $\mathrm{Fe}-\mathrm{O}$ bonds of iron oxide. This band continues to be present along all conjugation steps [61]. The presence of the Si-O-Si stretching vibration at about $993 \mathrm{~cm}^{-1}$, the bending vibrations of $\mathrm{C}-\mathrm{N}$ and $\mathrm{C}-\mathrm{H}$ at $1325 \mathrm{~cm}^{-1}$ and $1513 \mathrm{~cm}^{-1}$ as well as $\mathrm{N}-\mathrm{H}$ bands at $1558 \mathrm{~cm}^{-1}$ and $3741 \mathrm{~cm}^{-1}$ confirm the silanization with APTES (MNP-AP). The conjugation of PEA on silanized magnetite (MNP-AP-PEA) was confirmed by the absorption peak at $1041 \mathrm{~cm}^{-1}$ for the $\mathrm{C}-\mathrm{H}$ bending vibrations and at $1690 \mathrm{~cm}^{-1}$ related to the presence of $\mathrm{C}=\mathrm{O}$ stretching in the backbone of the polymer. Finally, the conjugation of OmpA and Laccase on the surface of MNP (MNP-PEA-OmpA-Laccase) was verified by the presence of the amide I and II bands at 1651 and $1513 \mathrm{~cm}^{-1}$, respectively.

(a)

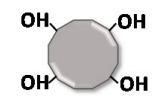

(b)

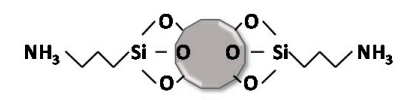

(c)

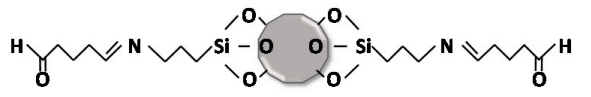

(d)

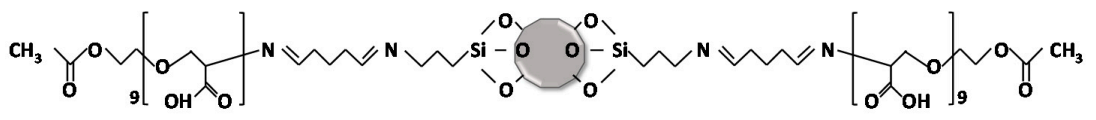

(e)

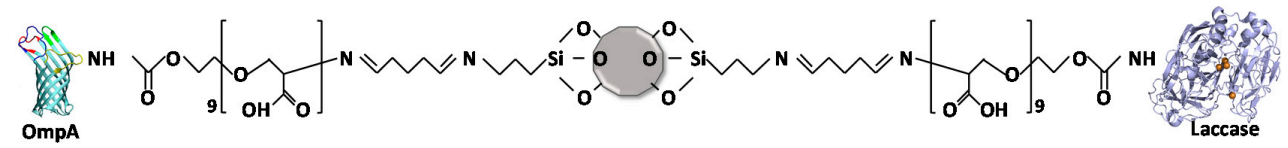

Scheme 1. Chemical structure along the intermediate steps of the synthesis to arrive to the final bionanocompound. (a) Magnetite $\left(\mathrm{Fe}_{3} \mathrm{O}_{4}\right)$ nanoparticle. (b) MNP-APTES functionalization. (c) MNP-APTES-Glutaraldehyde (GA). (d) MNP-APTES-GA-PEA nanocompound. (e) MNP-PEA-OmpA-Laccase bionanocompound. 

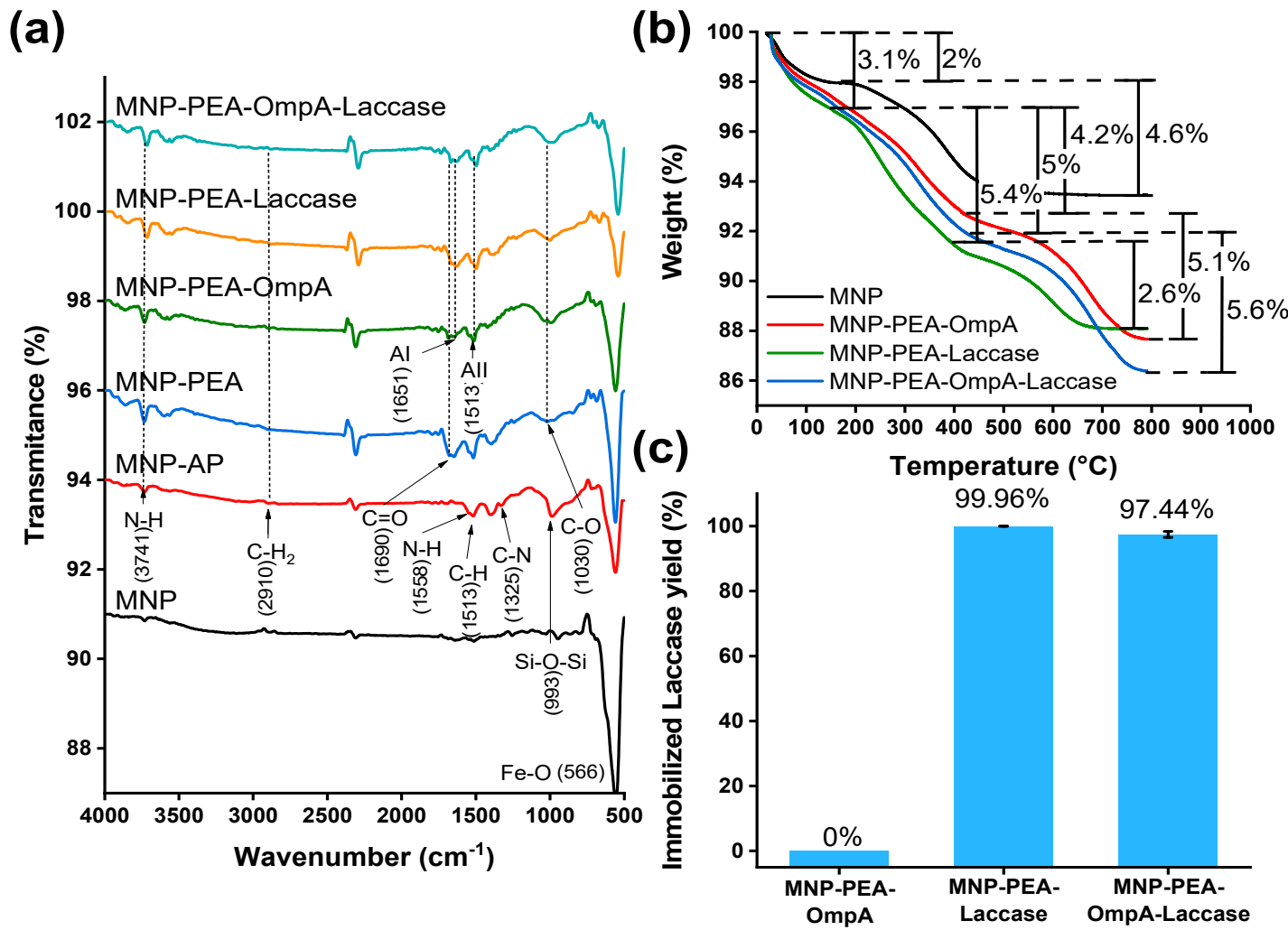

Figure 3. Characterizations of bionanocompounds: (a) FTIR spectra of MNP (black), silanized MNP (red), PEA coated MNP (blue), immobilized MNP-PEA-OmpA (green), MNP-Laccase (yellow) and MNP-PEA-OmpA-Laccase (turquoise). (b) Thermogravimetric assay (TGA) of MNP (black), MNP-PEA-OmpA (red), MNP-PEA-Laccase (green), and MNP-PEA-OmpA-Laccase (blue). (c) Immobilization yield (\%) of immobilized Laccase in all samples, as calculated from an enzymatic assay based on the oxidation of ABTS.

The secondary structural changes of immobilized OmpA were assessed with the aid of the second derivative of the FTIR spectra (Supplementary Figure S3). The results suggest that no significant secondary structural changes were observed for the protein after immobilization. The analyses were performed by direct comparison of the deconvoluted spectra prior and after immobilization [2]. In this regard, prior to immobilization vibrations corresponding to $\beta$-sheet are indicated at 1695, 1641, and $1625 \mathrm{~cm}^{-1}$. Additionally, a-helix structure and 310 -helix were identified at 1655 and $1664 \mathrm{~cm}^{-1}$, respectively [60]. After immobilization, the protein structure was conserved in their vibrations, as shown in Supporting Figure S3.

The conjugation efficiencies after each functionalization step were assessed with the aid of thermogravimetric analysis (TGA). TGA thermograms for bare magnetite (MNP) and the MNP-PEA-OmpA, MNP-PEA-Laccase, and MNP-PEA-OmpA-Laccase bionanocompounds are shown in Figure 3b. Magnetite exhibited a first weight loss of $2 \%$ at about $120{ }^{\circ} \mathrm{C}$ mainly due to dehydration. This was followed by a second weight loss of $4.6 \%$, which can be attributed to physically adsorbed organic compound residues left by the synthesis and functionalization processes [15]. For the bionanocompounds, the first dehydration weight losses approached $4.2 \%, 5.4 \%$, and $5 \%$ for MNP-PEA-OmpA, MNP-PEA-Laccase, and MNP-PEA-OmpA-Laccase, respectively. A second weight loss of 5.1\% and 2.6\% for MNP-PEA-OmpA (Red) and MNP-PEA-Laccase (green) indicated a similar immobilization efficiency for individual molecules. Co-immobilization (MNP-PEA-OmpA-Laccase) led to a second weight loss of $5.6 \%$, which shows a subtle improvement in efficiency. This could be attributed to the interplay and competition of protein-protein and protein-surface interactions during immobilization [69-72]. Further studies will be required to maximize the efficiencies. 


\subsection{Immobilization Yield Determination}

As a well-known oxide-reductase, the enzymatic activity of Laccase can be easily determined by measuring the rate of oxidation of 2,2'-azino-bis(3-ethylbenzothiazoline-6-sulphonic acid) (ABTS) [73]. For this purpose, after immobilization the activity of excess laccase in the medium was measured colorimetrically by monitoring the conversion of ABTS with respect to a calibration curve. An estimate of immobilization yield was calculated according to Equation (1) by comparing the activity of initially added laccase with that of the laccase remaining after immobilization, where $U$ remaining Laccase is the catalytic activity unit contained in the recovered immobilization medium and $U$ added Laccase is the unit initially added for immobilization according to the calculations reported in Supplementary Materials, Section SI2 [70,72].

$$
((\mathrm{U} \text { remaining Laccase }) /(\mathrm{U} \text { added Laccase })) \times 100 \text {. }
$$

The enzyme contents were estimated based on the enzymatic activity as described in Supplementary Materials, Section SI5 and Figure S4. This approach followed previous reports where the number of active immobilized molecules has been estimated by quantifying their catalytic activity towards a substrate with the aid of colorimetric or fluorescent methods [69,74-76]. Figure 3c shows the immobilization yield obtained according to content of Laccase. For the negative control (i.e., MNP-PEA-OmpA), the immobilization yield is $0 \%$. In contrast, MNP-PEA-Laccase and MNP-PEA-OmpA-Laccase bionanocompounds showed very high and similar immobilization yields of $99.96 \%$ and $97.44 \%$, respectively. This provides further evidence for the successful completion of the co-immobilization process and that such process is equally effective for molecules immobilized independently or simultaneously (even if the process occurs sequentially). According to the obtained yields, the amount of Laccase in the MNP-Laccase bionanocompounds corresponds to $0.49 \mathrm{U} / \mathrm{mg}_{\mathrm{MNP}}$ or $0.22 \mathrm{mg} / \mathrm{mg}_{\mathrm{MNP}}$ (Supplementary Materials, Section SI2 and Table S1). Similarly, the amount of immobilized enzyme in the MNP-PEA-OmpA-Laccase bionanocompounds was $0.11 \mathrm{mg} / \mathrm{mg}$ MNP or $0.23 \mathrm{U} / \mathrm{mg}_{\mathrm{MNP}}$. According to the TGA and enzymatic assays, we assumed that the equivalents of immobilized proteins were about the same, which allowed us to calculate that the amount of OmpA in the MNP-PEA-OmpA (99.96\% yield) was $0.12 \mathrm{mg} / \mathrm{mg}_{\mathrm{MNP}}$, while for the MNP-PEA-OmpA-Laccase (97.44\% yield) it was $0.06 \mathrm{mg} / \mathrm{mg}_{\mathrm{MNP}}$.

One of the most important properties of MNPs is the interfacial activity, which can be further improved by functionalization with interfacially active molecules-e.g., amphipathic surfactants. Several other materials have been coated on the surface of MNP to improve their porosity, stability, or affinity for specific interfaces [77]. Examples of them include APTES [40], polymers [14,41], carbon structures $[15,38,39]$, and enzymes $[69,78]$. The process of co-immobilization is intended to not only take advantage of the properties of MNPs, but also the properties of the interfaced molecules either independently or synergistically. This facilitates, for instance, one-step and one-pot strategies where just one system is possible to conduct multiple reactions. This approach is economically attractive as it considerably reduces the number of processing steps and consequently, the investment in equipment and involved personnel $[69,79]$. One major challenge is to assure the high immobilization efficiencies of active molecules. Here, such estimates for the proteins immobilized on the MNP-PEA-OmpA-Laccase bionanocompounds were somewhat problematic, considering that one of them (i.e., OmpA) shows no catalytic activity. Moreover, conventional methods for protein contents estimation such as BCA or Bradford are indifferent to the type of the protein and led to considerable error by the interference with the MNP support.

\subsection{O/W Emulsion Stability and Characterization}

The physical stability of the prepared $\mathrm{O} / \mathrm{W}$ emulsions was followed by monitoring the change in transmission signal and backscattering at room temperature in a Turbiscan Analyzer. This approach allowed quantification of destabilization phenomena such as sedimentation, creaming, aggregation, 
flocculation, and coalescence. The Turbiscan Stability Index (TSI) was also determined as a measure of the relative importance of the destabilization phenomena [80]. Low values of the TSI parameter usually indicate samples with a high stability. Figure 4 a shows the $\Delta$ Backscattering $(\Delta B S)$ of the prepared emulsion after $1 \mathrm{~h}$ (red layer). Two more experiments confirmed the reproducibility of the collected data (not shown). No destabilization phenomena were observed within the experimental window. Figure 4 a shows that the TSI parameter approached 0.8 after $1 \mathrm{~h}$ (black layer). This result is in line with the stability demonstrated by the $\triangle \mathrm{BS}$ data.
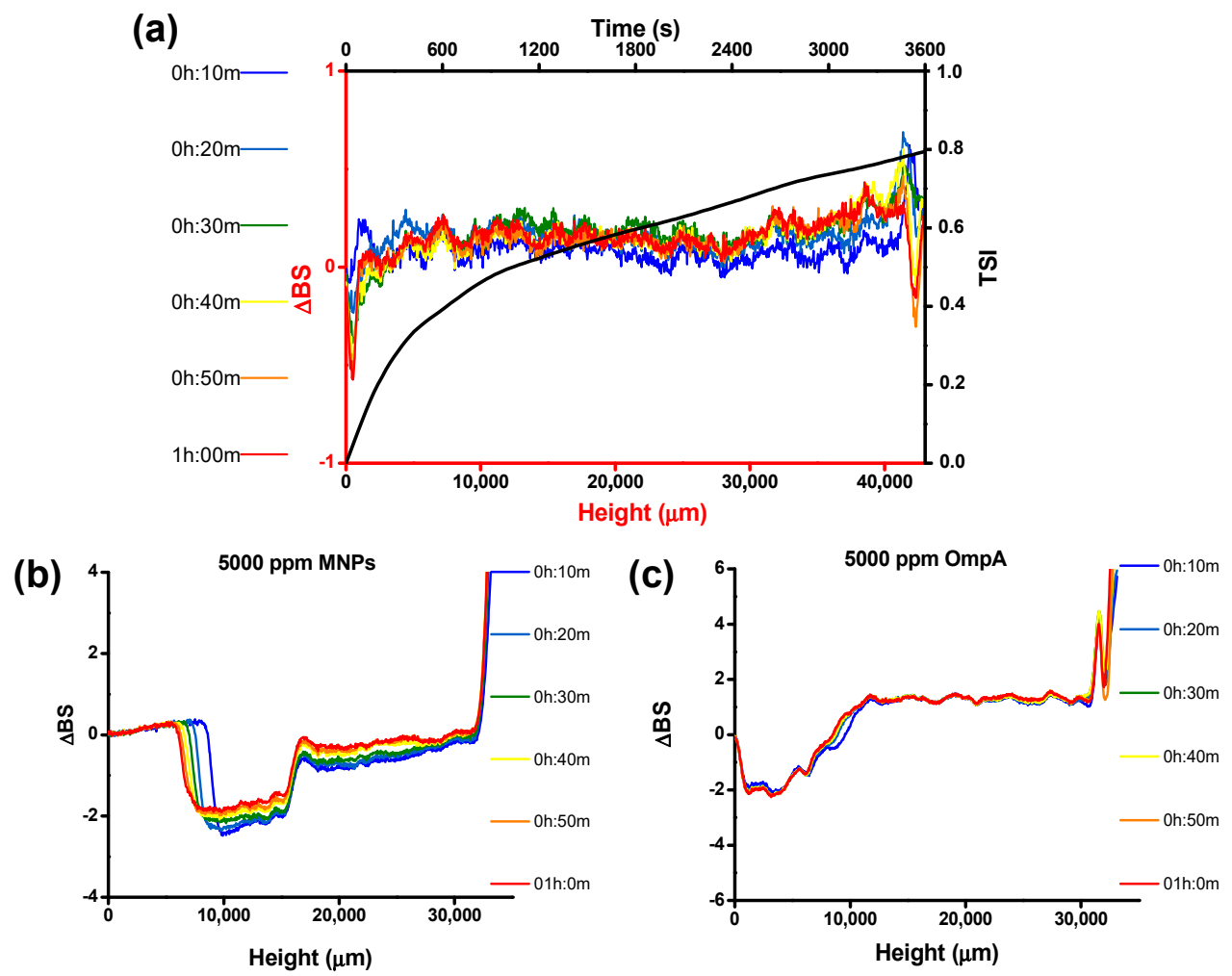

Figure 4. $\mathrm{O} / \mathrm{W}$ emulsion characterization. (a) $\Delta$ Backscattering $(\Delta \mathrm{BS})$ for a representative $\mathrm{O} / \mathrm{W}$ stabilized emulsion (red layer) and time evolution of the Turbiscan Stability Index (TSI) (black layer). Time evolution of $\triangle$ Backscattering $(\triangle \mathrm{BS})$ for $\mathrm{O} / \mathrm{W}$ emulsion prepared with $5000 \mathrm{ppm}$ of $(\mathbf{b})$ bare MNP and (c) free OmpA. The $\triangle \mathrm{BS}$ was monitored for $1 \mathrm{~h}$ at room temperature.

\subsection{Demulsification Effect of Free MNP and OmpA}

OmpA and MNP were added to the emulsion at concentrations of 200, 500, 1000, and 5000 ppm and their destabilizing effect was recorded with the aid of a Turbiscan instrument. We explored increased concentrations of demulsifier to analyze whether destabilizing phenomena might occur at a window of higher concentrations. The $\triangle \mathrm{BS}$ results for $\mathrm{O} / \mathrm{W}$ emulsions in the presence of OmpA and MNP are shown in Supplementary Figures S5 and S6, respectively. According to our results, at protein concentrations from 200 to 1000 ppm, changes in the stability of the emulsion were negligible; however, at 5000 ppm of both MNPs (Figure 4b) and OmpA (Figure 4c) significant changes were observable. As evidenced by the important changes in the $\triangle B S$ signal at the bottom of container in Figure $4 \mathrm{c}$, we hypothesize that at the beginning of the experiment insoluble protein clusters tend to precipitate and induce the sedimentation of some of the components of the emulsion. The decrease in $\triangle B S$ signals at the top of the container indicates the presence of bubbles. In contrast, the $\Delta B S$ signal profiles for destabilization in the presence of MNPs (Figure $4 \mathrm{~b}$ ) indicate creaming at the top of the container most likely due to the movement of oil drops to this region. Moreover, the $\triangle \mathrm{BS}$ decrease at the center of the container indicates clarification of the sample while the increase at the bottom is for the sedimented MNPs covered with HCO [81]. Interestingly, a closer inspection of the $\triangle B S$ profiles at 500 ppm MNP 
revealed a possible stabilizing effect. This was evidenced by profiles with even smoother tendencies than those observed for the blank (Figure 4a, red layer).

This agrees well with previous studies where superior stabilization is achieved by mixing nanoparticles with chemical surfactants in systems known as Pickering emulsions [82,83]. This stabilization phenomenon usually takes place when the particles exhibit sizes close to those of the emulsion droplets-i.e., $100 \mathrm{~nm}$ [82]. The particles can also be formed in situ by the presence of molecules such as proteins and starch $[37,84]$. MNPs have attracted considerable attention to alter the stability of emulsions and dispersions due to their high interfacial activity and the possibility to act in a controlled and reversible manner [83]. Recent reports showed that Pickering emulsion stabilization has been also achieved by the presence of MNPs of $\sim 100 \mathrm{~nm}$ at concentrations ranging from 0.1 to $5 \mathrm{wt} \%[40,83]$.

\subsection{Removal Efficiency}

We also tested MNP-PEA-OmpA and MNP-PEA-OmpA-Laccase for demulsification and estimated their remediation capabilities by looking at the changes in chemical composition via GC-MS. Under this perspective, we conducted bottle tests with MNP-PEA-OmpA and MNP-PEA-OmpA-Laccase bionanocompounds at a concentration of $5000 \mathrm{ppm}$. This corresponds to an approximate concentration of $600 \mathrm{ppm}$ of OmpA for the MNP-PEA-OmpA bionanocompound. In the case of the MNP-PEA-OmpA-Laccase bionanocompound, the corresponding concentrations were $300 \mathrm{ppm}$ for OmpA and $550 \mathrm{ppm}$ for Laccase. Finally, by assuming that all Laccase molecules remain active after immobilization, we calculated a catalytic activity of $18.4 \mathrm{U}$.

A representative optical microscopy image of crude oil-in-water $(\mathrm{O} / \mathrm{W})$ emulsions prepared in this work is shown in Figure 5d, BLANK. Oil drop size distribution was calculated from the images with the aid of the Image $J^{\circledR}$ software. Each sample was analyzed in triplicate at different $\mathrm{z}$ depths to find an average particle size distribution that approached 100-250 nm (not shown). Such an average size has been typically observed for miniemulsions or nano-emulsions, which generally exhibit superior stability and tolerance against sedimentation or creaming processes [85].

Figure $5 \mathrm{a}-\mathrm{c}$ show images of the macroscopic changes for the $\mathrm{O} / \mathrm{W}$ emulsion in the presence of the MNP-PEA-OmpA and MNP-PEA-OmpA-Laccase bionanocompounds. Figure 5a shows samples right after mixing with both bionanocompounds. This was considered the starting point and the blank for stability. Figure $5 \mathrm{~b}$ shows images of the samples after $1 \mathrm{~h}$ in the presence of the bionanocompounds. At this point, a slight clarification of the water phase was observed, which could be attributed to the sedimentation of bionanocompounds. Figure 5 c shows macroscopic images of the samples after the application of a magnetic field at the bottom of the glass container. The application of the field appears to help in accelerating the precipitation of dispersed solids and HCO drops. The bionanocompounds were successfully recovered after the process. Figure $5 \mathrm{~d}$ shows microscopy images of samples treated with the bionanocompounds and exposed to the magnetic field. The number and size of drops decreased considerably with respect to the control. Suspended solids (yellow arrow) were detected in all samples, which are most likely related to the asphaltenes or resins typically present in HCO. 
(a)

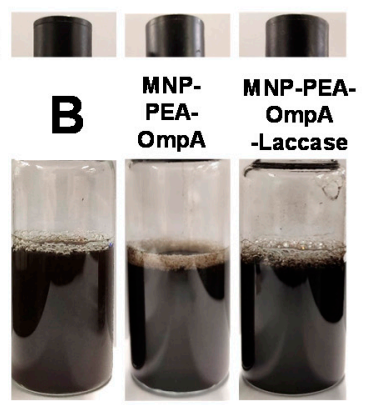

(b)

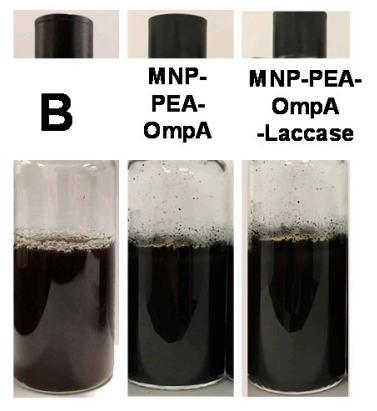

(c)

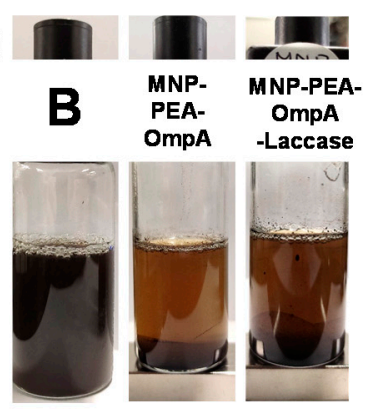

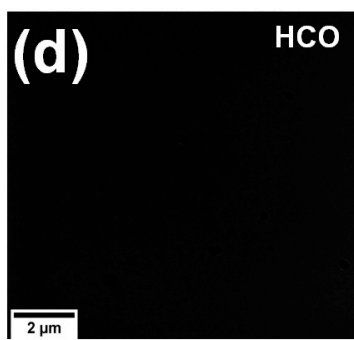
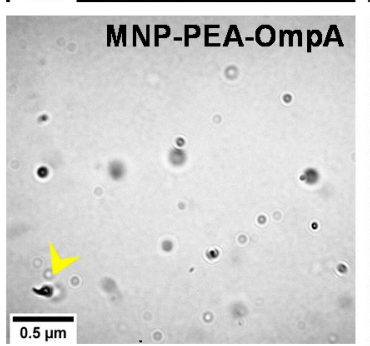

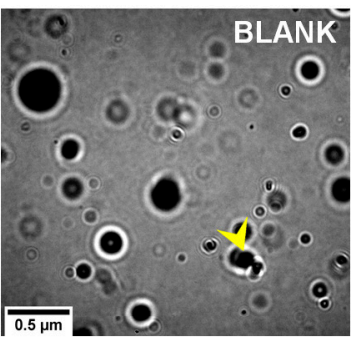

MNP-PEA-OMPA-Lacc

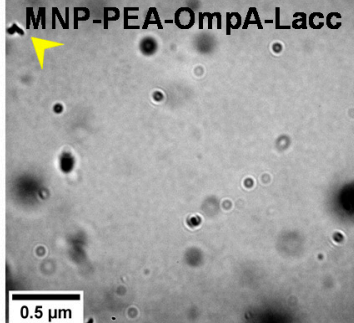

(e)

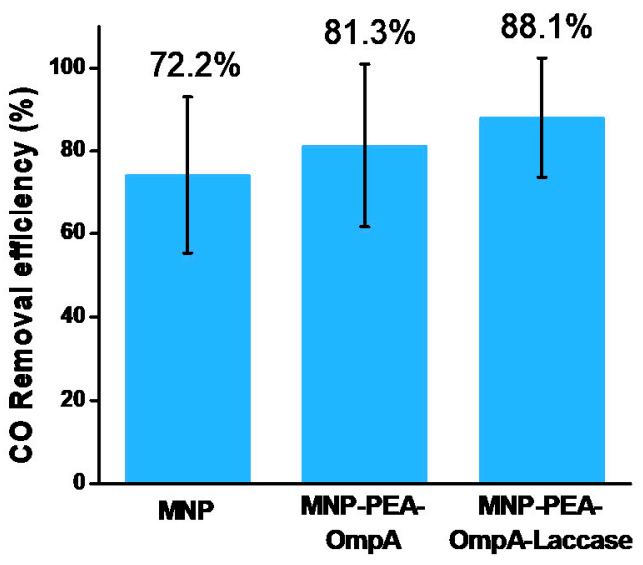

Figure 5. Demulsification assay of $\mathrm{O} / \mathrm{W}$ emulsions by MNP-PEA-OmpA and MNP-PEA-OmpA-Laccase at $5000 \mathrm{ppm}$. Blank of $\mathrm{O} / \mathrm{W}$ emulsion (B) and samples with MNP-PEA-OmpA and MNP-PEA-OmpA-Laccase (a) after preparation and initial exposure to treatments, (b) after $1 \mathrm{~h}$ of exposure, and (c) after $1 \mathrm{~h}$ of exposure and the application of an external magnetic field for MNP-PEA-OmpA and MNP-PREA-OmpA-Laccase bionanocompounds. (d) Optical microscopy images of emulsions before and after exposure to MNP-PEA-OmpA and MNP-PEA-OmpA-Laccase.

(e) HCO removal efficiency percentage for MNP, MNP-PEA-OmpA, and MNP-PEA-OmpA-Laccase.

Upon the recovery of the bionanocompounds from the treated samples, we measured the HCO remaining in them. Briefly, $1 \mathrm{~mL}$ of residual water was mixed with $3 \mathrm{~mL}$ of petroleum ether and sonicated in an ultrasonic bath for $5 \mathrm{~min}$. The mixture was decanted to separate the polar (water) from a non-polar phase (ether). The HCO preferentially partitioned into the ether phase, which was collected and quantified spectrophotometrically in a UV-VIS instrument at $225 \mathrm{~nm}$ (HCO detection wavelength [15]). Extracts from $\mathrm{O} / \mathrm{W}$ emulsions in the absence of treatment by the bionanocompounds were used to build a standard concentration curve (Supplementary Figure S7). Figure 5e shows the HCO removal efficiency for each treatment. The highest efficiency was achieved by the MNP-PEA-OmpA-Laccase bionanocompound, followed by the MNP-PEA-OmpA and finally the bare MNPs. This suggests that co-immobilization could lead to a synergistic interaction of proteins and HCO. Further evidence will be needed to support such a notion.

MNPs have the potential to enable numerous industry applications as their exceptional surface area and amenability for functionalization facilitate coupling of molecules with an ample range of functionalities. One of such applications is the separation of oil-water emulsions where the MNPs increase the density of the water present in the emulsion, thereby accelerating the rate of water settling. Additionally, cationic surfactant-coated MNPs have demonstrated that oil droplets are successfully separated from the negatively charged oil-in-water emulsions. This is in contrast with anionic surfactant-coated MNPs that showed no interfacial activity, thereby indicating that the stable adsorption of MNPs at the water/oil interface caused by electrostatic attractions plays a vital part in 
effective separation $[42,86]$. Additionally, several studies have found that the demulsifying effect in $\mathrm{O} / \mathrm{W}$ emulsions is enabled by the coalescence of droplets in the presence of a magnetic field. This is explained by the presence of the interfacially active MNPs at the interface capable of forming Pickering emulsions and subsequently promoting droplet accumulation by the influence of the magnetic force [77]. We hypothesize, therefore, that the separation yield may be increased by adding MNP-PEA-OmpA and MNP-OmpA-Laccase at higher concentrations, as has been previously shown elsewhere $[15,40,83]$. Dosages of the developed nanocompounds above $0.3 \mathrm{wt} \%$ showed higher HCO removal efficiencies.

\subsection{Gas Chromatography-Mass Spectrometry (GC-MS) Characterization of Residual Water}

The treated $\mathrm{O} / \mathrm{W}$ emulsions were also analyzed by GC-MS analysis to semi-quantitatively estimate changes in the composition of $\mathrm{HCO}$ with respect to the blank-i.e., untreated-O/W emulsion. Chromatograms of crude oil are shown in Supplementary Figure S8. Due to the complexity of crude oil, only peaks with the higher intensities (most abundant) were taken as a reference to estimate the changes. Supplementary Figure S8a shows the chromatogram for the blank, which presents three representative peaks at the retention times 21.9, 23.3, and $24.6 \mathrm{~s}$ (labeled as 9, 10, and 12). These peaks likely correspond to heptadecane, octadecane, and nonadecane, respectively. After treatment with the bionanocompounds, the intensities of these peaks declined, which is most likely due to their degradation. This was also the case of peaks 1, 13, and 15, which correspond to decamethylcyclopentasiloxane, methyl 14-methylpentadecanoate, and methyl cis-9-octadecenoate, respectively (Supplementary Figure S8b,c).

The relative areas of peaks for compounds in the treated samples were estimated with respect to the highest intensity peak in the blank (i.e., pentadecane, retention time $19.1146 \mathrm{~s}$ ). Table 2 summarizes the peaks where major changes in composition were observed, as evidenced by a reduction in the area under the curve. Additionally, we estimated the removal efficiencies (RE(\%)) for the relevant compounds by following the relation reported by Parthipan et al. [24]: RE $(\%)=100-($ As $\times 100 / A c)$, where As is the total area of peaks in every sample and Ac is the total area of peaks in the reference sample. Except for nonadecane, the removal efficiencies of the involved compounds were the highest for the MNP-PEA-OmpA-Laccase bionanocompound. This confirms that the designed system was not only capable of separating the emulsions but of biodegrading some of the most abundant compounds of HCO. Even though the semi-quantitative analysis presented here allowed us to confirm the potential of our bionanocompounds, a more robust chromatography analysis with the aid of internal standards will be useful for determining more precisely the removal efficiencies of the least abundant compounds.

Table 2. Changes in composition for the selected compounds present in $\mathrm{O} / \mathrm{W}$ samples after treatment with the bionanocompounds.

\begin{tabular}{|c|c|c|c|c|c|c|}
\hline \multirow[b]{2}{*}{ Peak $N^{\circ}$} & \multirow[b]{2}{*}{ Compound } & \multirow[b]{2}{*}{ Blank } & \multicolumn{2}{|c|}{ Relative Area } & \multicolumn{2}{|c|}{ Removal Efficiency } \\
\hline & & & $\begin{array}{l}\text { MNP-PEA- } \\
\text { OmpA }\end{array}$ & $\begin{array}{c}\text { MNP-PEA- } \\
\text { OmpA-Laccase }\end{array}$ & $\begin{array}{c}\text { MNP-PEA- } \\
\text { OmpA }\end{array}$ & $\begin{array}{c}\text { MNP-PEA- } \\
\text { OmpA-Laccase }\end{array}$ \\
\hline 5 & Pentadecane & 100.00 & 97.43 & 94.44 & 2.57 & 5.56 \\
\hline 7 & $\begin{array}{l}\text { Naphthalene, } \\
\text { 1,6,7-trimethyl }\end{array}$ & 34.91 & 33.77 & 31.84 & 3.28 & 8.79 \\
\hline 9 & Heptadecane & 73.24 & 58.18 & 53.25 & 20.56 & 27.30 \\
\hline 10 & Octadecane & 61.85 & 66.01 & 53.80 & 0.00 & 13.01 \\
\hline 11 & $\begin{array}{c}\text { Hexadecane, } \\
\text { 2,6,10,14- } \\
\text { tetramethyl }\end{array}$ & 48.41 & 25.31 & 23.90 & 47.71 & 50.62 \\
\hline 12 & Nonadecane & 53.35 & 50.12 & 63.84 & 6.04 & 0.00 \\
\hline 14 & Eicosane & 53.17 & 49.18 & 44.04 & 7.51 & 17.17 \\
\hline
\end{tabular}

\section{Conclusions}

Particulate materials have played a fundamental role in the oil and gas industry due to their ability to stabilize or destabilize colloidal systems. As a result, since the beginning of the century they have found several applications ranging from the formulation of drilling fluids to the treatment of effluents [37]. With the increase in the popularity of nanomaterials, the past two decades have seen 
their incursion in this industry in an attempt to enhance the efficiencies of numerous conventional processes [58,87-89]. For instance, different types of nanomaterials have been implemented for the treatment and recovery of emulsified effluents with moderate efficiencies [77,90]. In parallel, alternative remediation processes such as those based on biosurfactants have gained attention due to the possibility of operating at milder conditions [91,92]. In the same line, the removal of environmentally concerning compounds present in effluents has been addressed with the aid of enzymes and particularly Laccases. Here, we aimed at combining the potential of these technologies by synthesizing bionanocompounds based on MNPs, the biosurfactant protein OmpA, and the enzyme Laccase. The synthesis proceeded by the functionalization of MNPs with the polymeric surface spacer PEA, followed by their independent immobilization and the co-immobilization of the two proteins to obtain the MNP-PEA-OmpA, MNP-PEA-Laccase, and MNP-PEA-OmpA-Laccase bionanocompounds.

We synthesized the MNPs by chemical co-precipitation and confirmed a diameter of about $80 \mathrm{~nm}$ by DLS and TEM. Functionalization and protein immobilization were successfully confirmed via FTIR and TGA. The estimated efficiency of total protein immobilization approached about $2.5 \%, 5.0 \%$, and $5.5 \%$ for the MNP-PEA-OmpA, MNP-PEA-Laccase, and MNP-PEA-OmpA-Laccase bionanocompounds. These results suggested that immobilization took place under possible competing protein-protein and protein-surface interactions. The immobilization yield for the Laccase alone after co-immobilization (MNP-PEA-OmpA-Laccase) was estimated by a colorimetric assay based on ABTS to be $>97 \%$.

Demulsification assays were conducted for O/W $1 \mathrm{wt} \%$ emulsions. Separation was achieved at 5000 ppm of the MNP-PEA-OmpA and MNP-PEA-OmpA-Laccase bionanocompounds. This was further improved by applying an external magnetic field to reach $\mathrm{HCO}$ removal efficiencies of $81 \%$ and $88 \%$, respectively. These experiments demonstrated that the bionanocompounds can be recovered after treatment, which opens the possibility for potentially recycling them back into the process. The demulsifier activity of the recovered bionanocompounds needs to be assessed in detail.

The potential of the bionanocompounds in the bioremediation of emulsified effluents was tested by measuring changes in the composition of the selected compounds. The results indicate that, in the presence of the MNP-PEA-OmpA and MNP-PEA-OmpA-Laccase bionanocompounds, we observed degradation efficiencies in the range of $5 \%$ to $50 \%$. The highest degradation efficiencies were for heptadecane and hexadecane 2,6,10,14-tetramethyl, which approached $25 \%$ and 50\%, respectively. For future studies, we recommend the use of internal standards for a more quantitative determination. Overall, our results hold significant promise for the simultaneous separation and treatment of emulsified effluents from the oil and gas industry. Moreover, due to the remaining magnetic susceptibility, chances are high that they can be incorporated into a separation/treatment unit operating cyclically.

Supplementary Materials: The following are available online at http://www.mdpi.com/2079-4991/10/11/2278/s1. Figure S1: BSA standard concentration curve. Figure S2: Preparation protocol of CO/W stable emulsions. A. Heating of brine and crude oil phases to $60^{\circ} \mathrm{C}$. B. Mixer positioning where the $\mathrm{Da} / \mathrm{Dt}$ was maintained at about 1. Da corresponded to the propeller diameter and Dt that of the vessel. C. Addition of NP10 surfactant under vigorous mechanical agitation at 2000 RPM. D. Incorporation of pre-heated CO under vigorous mechanical agitation at 5000 RPM. The mixing process was carried out for $15 \mathrm{~min}$. Figure S3: Second derivative of free OmpA (green) and MNP-OmpA (magenta) in the region of Amide I $\left(1600\right.$ to $\left.1700 \mathrm{~cm}^{-1}\right)$. Figure S4: Remaining catalytic activity determination assay by ABTS oxidizing of samples. Figure S5: $\triangle B S$ recording of O/W emulsion in the presence of A. 200, B. 500, C. 1000 and D. 5000 ppm of free OmpA. Figure S6. $\triangle B S$ recording of O/W emulsion in the presence of A. 200, B. 500, C. 1000 and D. 5000 ppm of free MNP. Figure S7: Calibration curve for concentration of HCO in petroleum ether measured at $225 \mathrm{~nm}$ using petroleum ether as blank. Samples were prepared in serial dilutions from $10 \mu \mathrm{g} / \mathrm{mL}$. High content samples were disregarded from the curve due to oversaturation of the detector in the instrument. Figure S8: GC-MS chromatogram for treatments with A. Blank B. MNP-OmpA and C. MNP-OmpA-Laccase. Table S1: General Data and Values. Table S2. Most significant peaks identified.

Author Contributions: Conceptualization, J.F.O., A.F.G.-B., D.P., and J.C.C.; methodology, N.R.-M., D.P., J.F.O., and J.C.C.; software, N.R.-M.; validation, D.P., J.F.O., and J.C.C.; formal analysis, N.R.-M., D.P., J.C.C.; investigation, N.R.-M.; resources, J.F.O., A.F.G.-B., J.C.C.; data curation, N.R.-M.; writing-original draft preparation, N.R.-M.; writing-review and editing, N.R.-M., J.F.O., A.F.G.-B., D.P., and J.C.C.; visualization, N.R.-M.; supervision, D.P., J.F.O., and J.C.C.; project administration, J.F.O. and J.C.C.; funding acquisition, J.C.C. All authors have read and agreed to the published version of the manuscript.

Funding: This work was funded by Minciencias, Colombia, Grant 689-2018. 
Acknowledgments: Additional financial support was provided by the Departments of Biomedical Engineering, Chemical Engineering, and Electrical and Electronics Engineering at Universidad de los Andes. Feedback provided by Carolina Muñoz from the Department of Biomedical Engineering at Uniandes is gratefully acknowledged.

Conflicts of Interest: The authors declare no conflict of interest.

\section{References}

1. Yew, Y.P.; Shameli, K.; Miyake, M.; Ahmad Khairudin, N.B.B.; Mohamad, S.E.B.; Naiki, T.; Lee, K.X. Green biosynthesis of superparamagnetic magnetite $\mathrm{Fe}_{3} \mathrm{O}_{4}$ nanoparticles and biomedical applications in targeted anticancer drug delivery system: A review. Arab. J. Chem. 2020, 13, 2287-2308. [CrossRef]

2. Lopez-Barbosa, N.; Suárez-Arnedo, A.; Cifuentes, J.; Gonzalez Barrios, A.F.; Silvera Batista, C.A.; Osma, J.F.; Munõz-Camargo, C.; Cruz, J.C. Magnetite-OmpA Nanobioconjugates as Cell-Penetrating Vehicles with Endosomal Escape Abilities. ACS Biomater. Sci. Eng. 2020, 6, 415-424. [CrossRef]

3. Liu, L.L.; Li, X.T.; Zhang, N.; Tang, C.H. Novel soy $\beta$-conglycinin nanoparticles by ethanol-assisted disassembly and reassembly: Outstanding nanocarriers for hydrophobic nutraceuticals. Food Hydrocoll. 2019, 91, 246-255. [CrossRef]

4. Chen, Z.; Han, S.; Zhou, S.; Feng, H.; Liu, Y.; Jia, G. Review of health safety aspects of titanium dioxide nanoparticles in food application. NanoImpact 2020, 100224. [CrossRef]

5. López-Naranjo, E.J.; Hernández-Rosales, I.P.; Bueno-Durán, A.Y.; Martínez-Aguilar, M.L.; González-Ortiz, L.J.; Pérez-Fonseca, A.A.; Robledo-Ortiz, J.R.; Sánchez-Peña, M.J.; Manzano-Ramírez, A. Biosynthesis of silver nanoparticles using a natural extract obtained from an agroindustrial residue of the tequila industry. Mater. Lett. 2018, 213, 278-281. [CrossRef]

6. Abbasi, B.H.; Fazal, H.; Ahmad, N.; Ali, M.; Giglioli-Guivarch, N.; Hano, C. Nanomaterials for Cosmeceuticals: Nanomaterials-Induced Advancement in Cosmetics, Challenges, and Opportunities; Elsevier: Amsterdam, The Netherlands, 2020; ISBN 9780128222867.

7. Osma, J.F.; Stoytcheva Stilianova, M. Biosensors: Recent Advances and Mathematical Challenges; OmniaScience: Terrassa, Barcelona, Spain, 2014; ISBN 978-84-941872-0-9.

8. Zhang, G.; Quin, M.B.; Schmidt-Dannert, C. Self-Assembling Protein Scaffold System for Easy in Vitro Coimmobilization of Biocatalytic Cascade Enzymes. ACS Catal. 2018, 8, 5611-5620. [CrossRef]

9. Asal, M.; Özen, Ö.; Şahinler, M.; Baysal, H.T.; Polatoğlu, İ. An overview of biomolecules, immobilization methods and support materials of biosensors. Sens. Rev. 2018, 39. [CrossRef]

10. Nguyen, H.H.; Kim, M. An Overview of Techniques in Enzyme Immobilization. Appl. Sci. Converg. Technol. 2017, 26, 157-163. [CrossRef]

11. Acharya, A. Nanomaterial-Based Biomedical Applications in Molecular Imaging, Diagnostics and Therapy. In Biomolecules Immobilized Nanomaterials and Their Biological Applications; Springer: Berlin/Heidelberg, Germany, 2020; ISBN 978-981-15-4280-0.

12. IPIECA. Petroleum refinery waste management and minimization. In An IPIECA Good Practice Guide; IPIECA: Londond, UK, 2014.

13. Wong, S.F.; Lim, J.S.; Dol, S.S. Crude oil emulsion: A review on formation, classification and stability of water-in-oil emulsions. J. Pet. Sci. Eng. 2015, 135, 498-504. [CrossRef]

14. Liang, J.; Du, N.; Song, S.; Hou, W. Magnetic demulsification of diluted crude oil-in-water nanoemulsions using oleic acid-coated magnetite nanoparticles. Colloids Surf. A Physicochem. Eng. Asp. 2015, 466, 197-202. [CrossRef]

15. Xu, H.; Jia, W.; Ren, S.; Wang, J. Magnetically responsive multi-wall carbon nanotubes as recyclable demulsifier for oil removal from crude oil-in-water emulsion with different pH levels. Carbon N.Y. 2019, 145, 229-239. [CrossRef]

16. Wang, Q.; Puerto, M.C.; Warudkar, S.; Buehler, J.; Biswal, S.L. Recyclable amine-functionalized magnetic nanoparticles for efficient demulsification of crude oil-in-water emulsions. Environ. Sci. Water Res. Technol. 2018, 4, 1553-1563. [CrossRef]

17. Martínez-Palou, R.; Cerón-Camacho, R.; Chávez, B.; Vallejo, A.A.; Villanueva-Negrete, D.; Castellanos, J.; Karamath, J.; Reyes, J.; Aburto, J. Demulsification of heavy crude oil-in-water emulsions: A comparative study between microwave and thermal heating. Fuel 2013, 113, 407-414. [CrossRef] 
18. Isabel Briceno, M.; Salager, J.-L.; Luis Bracho, C. Heavy Hydrocarbon Emulsions Making Use of the State of the Art in Formulation Engineering. In Encyclopedic Handbook of Emulsion Technology; CRC Press: Boca Raton, FL, USA, 2001.

19. Martínez-Palou, R.; Reyes, J.; Cerón-Camacho, R.; Ramírez-de-Santiago, M.; Villanueva, D.; Vallejo, A.A.; Aburto, J. Study of the formation and breaking of extra-heavy-crude-oil-in-water emulsions-A proposed strategy for transporting extra heavy crude oils. Chem. Eng. Process. Process Intensif. 2015, 98, 112-122. [CrossRef]

20. Borah, D.; Yadav, R.N.S. Bioremediation of petroleum based contaminants with biosurfactant produced by a newly isolated petroleum oil degrading bacterial strain. Egypt. J. Pet. 2017, 26, 181-188. [CrossRef]

21. Sokól, W. Treatment of refinery wastewater in a three-phase fluidised bed bioreactor with a low density biomass support. Biochem. Eng. J. 2003, 15, 1-10. [CrossRef]

22. Baycan Parilti, N. Treatment of a Petrochemical Industry Wastewater by a Solar Oxidation Process Using The Box-Wilson Experimental Design Method. Ekoloji 2010, 19, 9-15. [CrossRef]

23. Volke, T.L.; Mulas, R.; Ercoli, E.; Fallis, A.; Vargas, P.; Cuéllar, R.; Dussán, J.; Cortón, E.; Viale, A.; Marta, M.; et al. Biorremediación de suelos: Desde el concepto a su aplicación. aplicación. J. Chem. Inf. Model. 2006, 23, 45. [CrossRef]

24. Parthipan, P.; Elumalai, P.; Sathishkumar, K.; Sabarinathan, D.; Murugan, K.; Benelli, G.; Rajasekar, A. Biosurfactant and enzyme mediated crude oil degradation by Pseudomonas stutzeri NA3 and Acinetobacter baumannii MN3. 3 Biotech 2017, 7, 1-17. [CrossRef]

25. Parhamfar, M.; Bayat, Z.; Parhamfar, M.; Hassanshahian, M.; Hosseini, S.S. Investigation of Oil-in-Water Emulsions Treatment by Crude Oil Degrading Bacteria and Coagulation with Cationic Polyacrylamide. J. Pet. Environ. Biotechnol. 2018, 9. [CrossRef]

26. Santos, D.K.F.; Rufino, R.D.; Luna, J.M.; Santos, V.A.; Sarubbo, L.A. Biosurfactants: Multifunctional biomolecules of the 21st century. Int. J. Mol. Sci. 2016, 17, 401. [CrossRef] [PubMed]

27. De Almeida, D.G.; Soares Da Silva, R.de.C.F.; Luna, J.M.; Rufino, R.D.; Santos, V.A.; Banat, I.M.; Sarubbo, L.A. Biosurfactants: Promising molecules for petroleum biotechnology advances. Front. Microbiol. 2016, 7, 1-14. [CrossRef] [PubMed]

28. Otzen, D.E. Proteins in a brave new surfactant world. Curr. Opin. Colloid Interface Sci. 2015, 20, 161-169. [CrossRef]

29. Banat, I.M.; Franzetti, A.; Gandolfi, I.; Bestetti, G.; Martinotti, M.G.; Fracchia, L.; Smyth, T.J.; Marchant, R. Microbial biosurfactants production, applications and future potential. Appl. Microbiol. Biotechnol. 2010, 87, 427-444. [CrossRef]

30. Patel, G.J. The Lipid Bilayer-Inserted Membrane Protein BamA of Escherichia coli Facilitates Insertion and Folding of Outer Membrane Protein A from Its Complex with Skp. Biochemistry 2013, 52, 3974-3986. [CrossRef]

31. Cardona Jaramillo, J.E.C.; Achenie, L.E.; Álvarez, O.A.; Carrillo Bautista, M.P.; González Barrios, A.F. The multiscale approach to the design of bio-based emulsions. Curr. Opin. Chem. Eng. 2020, 27, 65-71. [CrossRef]

32. Ishida, H.; Garcia-Herrero, A.; Vogel, H.J. The periplasmic domain of Escherichia coli outer membrane protein A can undergo a localized temperature dependent structural transition. Biochim. Biophys. Acta-Biomembr. 2014, 1838, 3014-3024. [CrossRef]

33. Wang, Y. The Function of OmpA in Escherichia coli. Biochem. Biophys. Res. Commun. 2002, 401, $396-401$. [CrossRef]

34. Tatiana, E.; Poveda, A.; Fernando, R.; Saiz, C. Emulsiones Agua-en-Crudo Pesado: Estudio de Separación de Fases a Través de la Proteina OmpA Pura e Inmovilizada en Nanopartículas de Magnetita; Uniandes: Bogotá, Colombia, 2018.

35. Aguilera-Segura, S.M.; Núñez Vélez, V.; Achenie, L.; Álvarez Solano, O.; Torres, R.; González Barrios, A.F. Peptides design based on transmembrane Escherichia coli's OmpA protein through molecular dynamics simulations in water-dodecane interfaces. J. Mol. Graph. Model. 2016, 68, 216-223. [CrossRef]

36. Tibaquirá Martinez, M.A.; Gonzalez Barrios, A. Exploración de la proteína transmembranal OmpA para la recuperación mejorada de hidrocarburos presentes en sistemas porosos. Bachelor's Thesis, Universidad de Los Andes, Bogotá, Colombia, 2014.

37. Umar, A.A.; Saaid, I.B.M.; Sulaimon, A.A.; Pilus, R.B.M. A review of petroleum emulsions and recent progress on water-in-crude oil emulsions stabilized by natural surfactants and solids. J. Pet. Sci. Eng. 2018, 165, 673-690. [CrossRef] 
38. Liu, J.; Wang, H.; Li, X.; Jia, W.; Zhao, Y.; Ren, S. Recyclable magnetic graphene oxide for rapid and efficient demulsification of crude oil-in-water emulsion. Fuel 2017, 189, 79-87. [CrossRef]

39. Zhang, B.; Hu, R.; Sun, D.; Wu, T.; Li, Y. Fabrication of Magnetite-Graphene Oxide/MgAl-Layered Double Hydroxide Composites for Efficient Removal of Emulsified Oils from Various Oil-in-Water Emulsions. J. Chem. Eng. Data 2018, 63, 4689-4702. [CrossRef]

40. Wang, X.; Shi, Y.; Graff, R.W.; Lee, D.; Gao, H. Developing recyclable pH-responsive magnetic nanoparticles for oil-water separation. Polymer (Guildf) 2015, 72, 361-367. [CrossRef]

41. Zhao, H.; Zhang, C.; Qi, D.; Lü, T.; Zhang, D. One-Step Synthesis of Polyethylenimine-Coated Magnetic Nanoparticles and its Demulsification Performance in Surfactant-Stabilized Oil-in-Water Emulsion. J. Dispers. Sci. Technol. 2019, 40, 231-238. [CrossRef]

42. Zhou, K.; Zhou, X.; Liu, J.; Huang, Z. Application of magnetic nanoparticles in petroleum industry: A review. J. Pet. Sci. Eng. 2020, 188, 106943. [CrossRef]

43. Kannel, P.R.; Gan, T.Y. Naphthenic acids degradation and toxicity mitigation in tailings wastewater systems and aquatic environments: A review. J. Environ. Sci. Health—Part A Toxic/Hazard. Subst. Environ. Eng. 2012, 47, 1-21. [CrossRef]

44. Kilpatrick, P.K. Water-in-crude oil emulsion stabilization: Review and unanswered questions. Energy Fuels 2012, 26, 4017-4026. [CrossRef]

45. Ikehata, K.; El-Din, M.G. Degradation of recalcitrant surfactants in wastewater by ozonation and advanced oxidation processes: A review. Ozone Sci. Eng. 2004, 26, 327-343. [CrossRef]

46. Ghasemi, Z.; Younesi, H.; Zinatizadeh, A.A. Preparation, characterization and photocatalytic application of TiO2/Fe-ZSM-5 nanocomposite for the treatment of petroleum refinery wastewater: Optimization of process parameters by response surface methodology. Chemosphere 2016, 159, 552-564. [CrossRef]

47. Gargouri, B.; Mhiri, N.; Karray, F.; Aloui, F.; Sayadi, S. Isolation and Characterization of Hydrocarbon-Degrading Yeast Strains from Petroleum Contaminated Industrial Wastewater. Biomed Res. Int. 2015, 2015. [CrossRef]

48. Van Do, T.; Le, C.T.N.; Do, L.T.; Dong, Q. Van Degradation of hydrocarbon components contaminated in oily waste-water collected in Doxa petroleum storage, Hanoi by microbial biofilm attached on coconut fiber. VNU J. Sci. Nat. Sci. Technol. 2017, 33. [CrossRef]

49. Agarwal, P.; Gupta, R.; Agarwal, N. A Review on Enzymatic Treatment of Phenols in Wastewater. J. Biotechnol. Biomater. 2016, 6. [CrossRef]

50. Zhao, L.; Cheng, Y.; Yin, Z.; Chen, D.; Bao, M.; Lu, J. Insights into the effect of different levels of crude oil on hydrolyzed polyacrylamide biotransformation in aerobic and anoxic biosystems: Bioresource production, enzymatic activity, and microbial function. Bioresour. Technol. 2019, 293, 122023. [CrossRef] [PubMed]

51. Pandey, K.; Singh, B.; Pandey, A.K.; Badruddin, I.J. Application of Microbial Enzymes in Industrial Waste Water Treatment. Int. J. Curr. Microbiol. Appl. Sci. 2017, 6, 1243-1254. [CrossRef]

52. Zhang, D.; Deng, M.; Cao, H.; Zhang, S.; Zhao, H. Laccase immobilized on magnetic nanoparticles by dopamine polymerization for 4-chlorophenol removal. Green Energy Environ. 2017, 2, 393-400. [CrossRef]

53. García-Morales, R.; García-García, A.; Orona-Navar, C.; Osma, J.F.; Nigam, K.D.P.; Ornelas-Soto, N. Biotransformation of emerging pollutants in groundwater by laccase from P. sanguineus CS43 immobilized onto titania nanoparticles. J. Environ. Chem. Eng. 2018, 6, 710-717. [CrossRef]

54. Vera, M.; Nyanhongo, G.S.; Guebitz, G.M.; Rivas, B.L. Polymeric microspheres as support to co-immobilized Agaricus bisporus and Trametes versicolor laccases and their application in diazinon degradation. Arab. J. Chem. 2020, 13, 4218-4227. [CrossRef]

55. Qiu, X.; Wang, S.; Miao, S.; Suo, H.; Xu, H.; Hu, Y. Co-immobilization of laccase and ABTS onto amino-functionalized ionic liquid-modified magnetic chitosan nanoparticles for pollutants removal. J. Hazard. Mater. 2020, 401, 123353. [CrossRef]

56. Zdarta, J.; Meyer, A.S.; Jesionowski, T.; Pinelo, M. A general overview of support materials for enzyme immobilization: Characteristics, properties, practical utility. Catalysts 2018, 8, 92. [CrossRef]

57. Shriver-Lake, L.C.; Anderson, G.P.; Taitt, C.R. Effect of Linker Length on Cell Capture by Poly(ethylene glycol)-Immobilized Antimicrobial Peptides. Langmuir 2017, 33, 2878-2884. [CrossRef]

58. Deb, A.; Vimala, R. Camptothecin loaded graphene oxide nanoparticle functionalized with polyethylene glycol and folic acid for anticancer drug delivery. J. Drug Deliv. Sci. Technol. 2018, 43, 333-342. [CrossRef] 
59. Acosta, M.; Reyes, L.H.; Cruz, J.C.; Pradilla, D. Demulsification of Colombian Heavy Crude Oil (W/O) Emulsions: Insights into the Instability Mechanisms, Chemical Structure, and Performance of Different Commercial Demulsifiers. Energy Fuels 2020, 34, 5665-5678. [CrossRef]

60. Yang, H.; Yang, S.; Kong, J.; Dong, A.; Yu, S. Obtaining information about protein secondary structures in aqueous solution using Fourier transform IR spectroscopy. Nat. Protoc. 2015, 10, 382-396. [CrossRef] [PubMed]

61. Feng, B.; Hong, R.Y.; Wang, L.S.; Guo, L.; Li, H.Z.; Ding, J.; Zheng, Y.; Wei, D.G. Synthesis of Fe ${ }_{3} \mathrm{O}_{4} / \mathrm{APTES} / \mathrm{PEG}$ diacid functionalized magnetic nanoparticles for MR imaging. Colloids Surf. A Physicochem. Eng. Asp. 2008, 328, 52-59. [CrossRef]

62. dos Santos, R.G.; Bannwart, A.C.; Briceño, M.I.; Loh, W. Physico-chemical properties of heavy crude oil-in-water emulsions stabilized by mixtures of ionic and non-ionic ethoxylated nonylphenol surfactants and medium chain alcohols. Chem. Eng. Res. Des. 2011, 89, 957-967. [CrossRef]

63. Eftekhardadkhah, M.; Kløcker, K.N.; Trapnes, H.H.; Gawełe, B.; Øye, G. Composition and Dynamic Adsorption of Crude Oil Components Dissolved in Synthetic Produced Water at Different pH Values. Ind. Eng. Chem. Res. 2016, 55, 3084-3090. [CrossRef]

64. Eftekhardadkhah, M.; Øye, G. Correlations between crude oil composition and produced water quality: A multivariate analysis approach. Ind. Eng. Chem. Res. 2013, 52, 17315-17321. [CrossRef]

65. Tamm, L.K.; Tatulian, S.A. Infrared spectroscopy of proteins and peptides in lipid bilayers. Q. Rev. Biophys. 1997, 30, 365-429. [CrossRef]

66. Gonzalez Barrios, A.F.; Zuo, R.; Ren, D.; Wood, T.K. Hha, YbaJ, and OmpA regulate Escherichia coli K12 biofilm formation and conjugation plasmids abolish motility. Biotechnol. Bioeng. 2005, 93, 188-200. [CrossRef]

67. Petcharoen, K.; Sirivat, A. Synthesis and characterization of magnetite nanoparticles via the chemical co-precipitation method. Mater. Sci. Eng. B Solid-State Mater. Adv. Technol. 2012, 177, 421-427. [CrossRef]

68. Bruce, J.; Berne, C. Dynamic Light Scattering: With Applications to Chemistry, Biology, and Physics; Courier Corporation; Dover Publications: Garden City, NY, USA, 2000.

69. Hepziba Suganthi, S.; Swathi, K.V.; Biswas, R.; Basker, S.; Ramani, K. Co-immobilization of multiple enzymes onto surface-functionalized magnetic nanoparticle for the simultaneous hydrolysis of multiple substrates containing industrial wastes. Appl. Nanosci. 2019, 9, 1439-1457. [CrossRef]

70. Fan, L.; Wang, J.; Zhang, X.; Sadeghzadeh, S.M.; Zhiani, R.; Shahroudi, M.; Amarloo, F. Co-immobilization of Laccase and TEMPO onto Glycidyloxypropyl Functionalized Fibrous Phosphosilicate Nanoparticles for Fixing $\mathrm{CO}_{2}$ into $\beta$-Oxopropylcarbamatesin. Catal. Lett. 2019, 149, 3465-3475. [CrossRef]

71. Li, C.; Jiang, S.; Zhao, X.; Liang, H. Co-immobilization of enzymes and magnetic nanoparticles by metal-nucleotide hydrogelnanofibers for improving stability and recycling. Molecules 2017, 22, 179. [CrossRef] [PubMed]

72. Gür, S.D.; İdil, N.; Aksöz, N. Optimization of Enzyme Co-Immobilization with Sodium Alginate and Glutaraldehyde-Activated Chitosan Beads. Appl. Biochem. Biotechnol. 2017, 1-15. [CrossRef]

73. Campaña, A.L.; Florez, S.L.; Noguera, M.J.; Fuentes, O.P.; Puentes, P.R.; Cruz, J.C.; Osma, J.F. Enzyme-based electrochemical biosensors for microfluidic platforms to detect pharmaceutical residues in wastewater. Biosensors 2019, 9, 41. [CrossRef]

74. Zdarta, J.; Bachosz, K.; Degórska, O.; Zdarta, A.; Kaczorek, E.; Pinelo, M.; Meyer, A.S.; Jesionowski, T. Co-immobilization of glucose dehydrogenase and xylose dehydrogenase as a new approach for simultaneous production of gluconic and xylonic acid. Materials (Basel) 2019, 12, 3167. [CrossRef]

75. Caparco, A.A.; Bommarius, B.R.; Bommarius, A.S.; Champion, J.A. Protein-inorganic calcium-phosphate supraparticles as a robust platform for enzyme co-immobilization. Biotechnol. Bioeng. 2020. [CrossRef]

76. Arana-Peña, S.; Mendez-Sanchez, C.; Rios, N.S.; Ortiz, C.; Gonçalves, L.R.B.; Fernandez-Lafuente, R. New applications of glyoxyl-octyl agarose in lipases co-immobilization: Strategies to reuse the most stable lipase. Int. J. Biol. Macromol. 2019, 131, 989-997. [CrossRef]

77. Simonsen, G.; Strand, M.; Øye, G. Potential applications of magnetic nanoparticles within separation in the petroleum industry. J. Pet. Sci. Eng. 2018, 165, 488-495. [CrossRef]

78. Wu, E.; Li, Y.; Huang, Q.; Yang, Z.; Wei, A.; Hu, Q. Laccase immobilization on amino-functionalized magnetic metal organic framework for phenolic compound removal. Chemosphere 2019, 233, 327-335. [CrossRef]

79. Kandasamy, R. A novel single step synthesis and surface functionalization of iron oxide magnetic nanoparticles and thereof for the copper removal from pigment industry effluent. Sep. Purif. Technol. 2017. [CrossRef] 
80. Li, Y.; Wang, Y.; Kang, W.; Xu, B.; An, F.; Shan, X.; Liu, J. Stability mechanism of W/O crude oil emulsion stabilized by polymer and surfactant. Colloids Surf. A Physicochem. Eng. Asp. 2011, 384, 555-560. [CrossRef]

81. Formulaction SAS Printing Status. Turbiscan LAB Instrum. Users Guide. 2013, p. 96. Available online: https://www.formulaction.com/en/our-solutions/stability-and-shelf-life (accessed on 7 September 2020).

82. Chevalier, Y.; Bolzinger, M.A. Emulsions stabilized with solid nanoparticles: Pickering emulsions. Colloids Surf. A Physicochem. Eng. Asp. 2013, 439, 23-34. [CrossRef]

83. Yang, H.; Zhang, H.; Peng, J.; Zhang, Y.; Du, G.; Fang, Y. Smart magnetic ionic liquid-based Pickering emulsions stabilized by amphiphilic $\mathrm{Fe}_{3} \mathrm{O}_{4}$ nanoparticles: Highly efficient extraction systems for water purification. J. Colloid Interface Sci. 2017, 485, 213-222. [CrossRef] [PubMed]

84. Dickinson, E. Use of nanoparticles and microparticles in the formation and stabilization of food emulsions. Trends Food Sci. Technol. 2012, 24, 4-12. [CrossRef]

85. Anton, N.; Vandamme, T.F. Nano-emulsions. Handb. Nanopart. 2015, 10, 93-116. [CrossRef]

86. Ko, S.; Kim, E.S.; Park, S.; Daigle, H.; Milner, T.E.; Huh, C.; Bennetzen, M.V.; Geremia, G.A. Oil droplet removal from produced water using nanoparticles and their magnetic separation. In Proceedings of the Proceedings-SPE Annual Technical Conference and Exhibition, Dubai, UAE, 26-28 September 2016.

87. Adeleye, A.S.; Conway, J.R.; Garner, K.; Huang, Y.; Su, Y.; Keller, A.A. Engineered nanomaterials for water treatment and remediation: Costs, benefits, and applicability. Chem. Eng. J. 2016, 286, 640-662. [CrossRef]

88. Subramani, A.; Jacangelo, J.G. Emerging desalination technologies for water treatment: A critical review. Water Res. 2015, 75, 164-187. [CrossRef]

89. Maity, D.; Chandrasekharan, P.; Feng, S.S.; Jun, D. Synthesis and studies of APTES functionalized magnetite nanoparticles. In Proceedings of the ICONN 2010-2010 International Conference on Nanoscience and Nanotechnology, Sydney, NSW, Australia, 22-26 February 2010; pp. 94-97. [CrossRef]

90. Pradilla, D.; Ramírez, J.; Zanetti, F.; Álvarez, O. Demulsifier Performance and Dehydration Mechanisms in Colombian Heavy Crude Oil Emulsions. Energy Fuels 2017, 31, 10369-10377. [CrossRef]

91. Rocha e Silva, N.M.P.; Meira, H.M.; Almeida, F.C.G.; Soares da Silva, R.D.C.F.; Almeida, D.G.; Luna, J.M.; Rufino, R.D.; Santos, V.A.; Sarubbo, L.A. Natural Surfactants and Their Applications for Heavy Oil Removal in Industry. Sep. Purif. Rev. 2019, 48, 267-281. [CrossRef]

92. Karlapudi, A.P.; Venkateswarulu, T.C.; Tammineedi, J.; Kanumuri, L.; Ravuru, B.K.; ramu Dirisala, V.; Kodali, V.P. Role of biosurfactants in bioremediation of oil pollution-a review. Petroleum 2018, 4, 241-249. [CrossRef]

Publisher's Note: MDPI stays neutral with regard to jurisdictional claims in published maps and institutional affiliations.

(C) 2020 by the authors. Licensee MDPI, Basel, Switzerland. This article is an open access article distributed under the terms and conditions of the Creative Commons Attribution (CC BY) license (http://creativecommons.org/licenses/by/4.0/). 